\title{
USES OF THE SUMMARY POWER TO SUSPEND RATES: AN EXAMINATION OF FEDERAL REGULATORY AGENCY PRACTICES
}

\author{
RALPH S. SPRITZER †
}

\section{Introduction and Summary}

The familiar power of a federal regulatory commission to suspend a proposed tariff change filed by a carrier or utility involves more than the power-itself of more than passing significance-to delay the effective date of the proposed change. A failure by a commission to suspend means that the burden of any future effort to dislodge or modify the new rate will fall upon the challenger, whereas an exercise of the suspension power conferred by the typical regulatory statute shifts the burden of justification to the proponent of the change. ${ }^{1}$ Contested rate proceedings are characteristically protracted, and the burden may be costly, as well as difficult, to sustain. ${ }^{2}$ A regulated company may

$\dagger$ Professor of Law, University of Pennsylvania. B.S. 1937, LL.B. 1940, Columbia University. Member, New York Bar. This Article is based upon a report prepared by the author as consultant to the Administrative Conference of the United States. Although the report is currently under consideration by the Conference's Committee on Rulemaking, no conclusions have been reached by the Committee, and the matter has not been considered by the Conference. The views expressed are solely those of the author. Early publication has been authorized by the Conference in order to elicit comment from interested persons.

1 This is illustrated by the case of Atlantic Refining Co. v. Public Serv. Comm'n, 360 U.S. 378 (1959) (the CATCO case), in which producers of natural gas had refused to accept certificates issued under $\$ 7$ of the Natural Gas Act, 15 U.S.C. $\$ 717 f$ (1970), authorizing sales at a price lower than they had proposed, even though the certificates would have permitted them to file immediately (subject to the Commission's exercise of its power to suspend under $\$ 4$ of the Natural Gas Act, 15 U.S.C. $\$ 717 c(1970)$ ) for an increase to that level. The Federal Power Commission thereupon retreated from its earlier position and issued certificates at the price sought by the producers, stating that assurance of supply was the dominant consideration and that it would promptly initiate an investigation under $\$ 5$ of the Gas Act, 15 U.S.C. $\$ 717 \mathrm{~d}(1970)$, into the reasonableness of the rate. Commissioner Connole dissented from this action, expressing the opinion that the "controlling reason" for the producers' refusal to accept the certificates previously tendered was "their preference for a proceeding in which the burden would be on the Commission to establish that the rate was more than reasonable." Continental Oil Co., 17 F.P.C. 880,885 (1957). As emphasized by the Supreme Court in reversing the agency, a further consequence was that consumers would not have the benefit of $\S 4$ 's provision for refund while protracted investigation was being conducted under $\$ 5$, which provides only for prospective relief.

284 ICC ANN. REP. 114-15 (1970) gives that agency's data as to the average time from the date of filing to the date of closing a case. In motor carrier investigation and suspension cases, the average time is 9.5 months in instances in which no exceptions are taken to the recommended decision of the hearing officer. In instances in which exceptions are taken and the final report is issued by the Commission, the figure is 25 months. In instances in which an initial report is waived and the final report issued by the Commission, the period averages 5.6 months. In rail carrier investigation and suspension cases, the comparable figures are 21 months, 20 months, and 7.7 months, respectively. These averages are based upon those cases that were decided during fiscal year 1970 . The Annual Report also furnishes data covering cases during the 2 preceding fiscal years. 
conclude from an agency's decision to suspend that the game is not worth the candle and withdraw its proposal. It is particularly likely to do so if it believes that the action reflects hostility to the change. Or, short of abandoning the proposal, the company may seek to determine whether a modified version might escape the ban of suspension. Thus, the use, or threatened use, of the power to suspend gives an agency means of exerting leverage. If so disposed, it may be able to influence or deter conduct by the regulated company through a process that is at once summary and, at least in ordinary circumstances, unreviewable. If one likens the administrative power to suspend to the power of a court to grant a preliminary injunction, it might be said that the situation is one in which the power to grant preliminary injunctive relief may, as a practical matter, carry with it the power to dispose of the whole case or, short of that, to shape the merits.

To say that this summary power has pervasive implications for the regulatory process and for the conduct of the business of the regulated companies is not necessarily to suggest that its exercise should be curtailed or that it should be subjected to a greater measure of judicial surveillance because of its potential for misuse. Evidence abounds for the proposition that full-blown rate proceedings are a drain upon the capacities of the administrative agencies and are very costly. ${ }^{3}$ Accordingly, as an a priori matter there is reason to look with some favor upon a device that, apart from the other purposes that it may serve, provides a means of disposing of a significant amount of potential litigation without the necessity of plenary proceedings. An attempt to strike a balance between the danger that the power to suspend will be abused and the benefits to be derived from a reduction of administrative litigation requires an appraisal of the system in operation.

Neither the agencies nor the respective industries subject to their jurisdiction are all of a piece; the system does not work in precisely the same way in all of the regulatory areas in which it is employed. The purpose of this Article is to consider the uses of the suspension power, together with certain closely related matters, as it has been employed by the principal federal agencies that engage in ratemaking functions; to offer an appraisal of past performance and results; and to explore the possibility of introducing certain safeguards and improvements into the process. The agencies that will be examined are the Interstate

3 To quantify the costs is quite another matter. It may be noted that Professor Paul W. MacAvoy of the Massachusetts Institute of Technology is engaged in a series of studies, sponsored by the Brookings Institution, that aims at a comprehensive analysis of the costs and benefits of the regulatory activities of the Federal Power Commission. See P. MacAvoy, The Effectiveness of the Federal Power ComMISSION (The Brookings Institution Reprint No. 189, 1971). 
Commerce Commission, the Federal Communications Commission, the Civil Aeronautics Board, and the Federal Power Commission.

The Interstate Commerce Commission (ICC) is examined first because the power of suspension was initially fashioned by amendments to the Interstate Commerce Act and because the pertinent provisions of that statute served as a model for the cognate provisions of later regulatory statutes. The ICC also provides a natural starting point because it has developed settled procedures and because its experience has produced a substantial body of data. The heavy volume of rate changes with which it must contend under the present scheme of pervasive regulation is a source of many of its problems.

The history of the Commerce Act provisions ${ }^{4}$ persuasively demonstrates a congressional purpose to confide to the exclusive discretion of the administrative agency the decision whether to suspend. A study of the ICC's procedures and performance leads to several conclusions. In some classes of cases a more effective method of giving notice to those who may be affected by proposed changes is needed. The Commission should assume a greater burden in screening tariff changes in areas in which experience has shown that outside intervenors are not likely to apprise the Commission of the need for investigation. The Commission should be empowered to issue "stop" orders extending for an additional twenty days the thirty-day period in which it must decide the issue of suspension-a suggestion designed to enable it to deal with the difficult cases on a more informed basis than the existing pressures of time permit. When it exercises the power to suspend, the Commission should undertake to state as specifically as practicable the reasons for its action, instead of relying upon the mere recitation of statutory criteria - a procedural improvement that would provide an informed basis for a carrier's decision whether to stand on its proposal in its existing form, and, if it chose to do so, for undertaking to meet its burden of justification.

The discussion of the remaining three agencies concentrates largely on those aspects of ratemaking that are distinctive attributes of each and treats less extensively those facets of their regulatory experiences that are fairly common to all.

The distinctive feature of the Federal Communications Commission's (FCC's) common carrier regulation, which principally involves the Bell Telephone System, is the agency's substantial reliance upon informal bargaining with the American Telephone and Telegraph Company (A.T. \& T.) in advance of filing. This process, which excludes other parties, avoids both the occasion for suspending rates and the

4 See text accompanying notes 15-37 infra. 
conduct of formal proceedings. There is serious question whether such negotiations (in which, of course, the agency's chief bargaining tool is its ability to invoke its formal powers) can be reconciled with the agency's statutory role as an independent reviewing authority empowered to examine and revise carrier-initiated rates. Moreover, the regulatory approach adopted by the FCC, although expeditious in the short run, has inhibited the development of an adequate and competent agency staff, delayed the development of an adequate methodology of regulation, and resulted in a conspicuous failure to formulate visible and consistent standards. These deficiencies have become manifest in the course of the agency's first comprehensive investigation of A.T. \& T., initiated in 1965 and still in progress.

While the $\mathrm{FCC}$ has minimized formal proceedings by working matters out with the carrier in advance of the filing of proposed tariff changes, the Civil Aeronautics Board (CAB) has frequently utilized the device of a "speaking" suspension order to achieve that result. A "speaking" order is one in which the Board, at the time it finds a carrier's proposal suspect, not only suspends the rate change but advises the carriersometimes after consultations between Board members and the carrierof the kind of substituted proposal that would be accepted without interdiction. This procedure recently received judicial scrutiny in Moss v. $C A B,{ }^{5}$ a case involving general increases in domestic passenger fares sought by the major trunkline carriers. The Board carried this tactic to the point of issuing an order of suspension that set forth what the reviewing court later termed "a complete and innovative scheme for setting all passenger rates for the continental United States." " It was made plain that rates filed in accordance with the Board's formula would be permitted to take prompt effect and that rates not so conforming would be suspended and investigated. The court of appeals, pointing to the carriers' pressing need for added revenues, concluded that the "advice" was coercive, not merely advisory, and that the Board action amounted to a prescription of rates. So viewed, its order was invalid because there had been no public hearings and no findings by the Board demonstrating that its formula was consistent with the ratemaking standards of the Federal Aviation Act. ${ }^{7}$

Analysis of the decision does not lead to the conclusion that an agency's order of suspension becomes reviewable merely because it explains - as the regulatory statutes indeed require-the reasons for suspension. A workable distinction can be drawn between an order of

5430 F.2d 891 (D.C. Cir. 1970).

6 Id. at 899 .

749 U.S.C. $\$ 1482$ (e) (1970). 
suspension that identifies the aspects of a carrier's proposal deemed questionable and one that seeks to use the agency's power to delay and deny as a means of inducing a carrier to adopt a proposal fashioned by the agency.

As noted above, the Moss court observed that the pressures upon the carriers were well-nigh irresistible because of their immediate revenue needs. It suggested that in such circumstances it would be permissible to grant rate relief during the course of a formal proceeding by an interim order based on interim findings. Existing statutory provisions, however, lack flexibility. An agency has discretion to suspend in toto or not at all. But there is no provision for the common situation in which an agency can make a preliminary judgment that a proposal appears justifiable in part and questionable in part.

An expeditious and satisfactory means of meeting such a situation would be for Congress to authorize ratemaking agencies to allow partial and temporary increases, subject to appropriate conditions, at the time they exercise their power of suspension.

The last agency considered, the Federal Power Commission (FPC), has not used the power of suspension as a bargaining tool. Unlike the other regulatory agencies, however, it has had signal success in settling cases after they have been set down for hearing. This has been especially notable in pipeline rate cases. Even though these are invariably multiparty proceedings, settlement of some or all of the issues was achieved in more than half the cases during the period 1960-1970. Even when the agreement to settle was not reached until the conclusion of the evidentiary hearing, the Commission saved much time by dispensing with an initial decision by an examiner and the customary briefing procedures.

Several factors have played a part. FPC practice requires the parties to submit and exchange relevant data and expert testimony in written form at an early stage. The agency's staff plays an active role, checking data and providing information obtainable through the Commission's resources. Thus negotiation can take place on the basis of a reliable core of knowledge and with the assistance of the agency's staff. Moreover, the examiners have frequently been effective in using the pre-hearing conference to narrow and focus the issues. Not least important, the methodology and the standards employed in these rate cases are settled and known. With the results of litigation predictable within a fairly narrow range, the prospect of agreement by negotiation is considerably enhanced.

A question that recurs in the context of ratemaking is the extent of an agency's authority to terminate an evidentiary hearing in a rate 
case when there is substantial, but less than unanimous, agreement as to an appropriate disposition among the principally affected parties. ${ }^{8}$ The Administrative Procedure Act authorizes procedures for the submission of all or part of the evidence in a rate case in written form "when a party will not be prejudiced thereby." 9 The provision, however, has restricted utility because of the inherent difficulty of predicting results of cross-examination. Determination on the basis of written submissions should also be authorized, though left to the agency's discretion, when a substantial majority of those primarily affected by a rate proposal support an agreement of settlement. In such circumstances, the considerations favoring expedition outweigh the speculative gain that may result from giving a dissident a more extensive right to pursue trial-type procedures.

\section{The Interstate Commerce Commission}

The Interstate Commerce Act vests in the ICC extensive control over the rates and charges of regulated companies. ${ }^{10}$ Changes in published rates may become effective only after thirty days from the filing of notice with the Commission. ${ }^{11}$ After the filing of any schedule indicating a new rate, or regulation or practice affecting a rate, the ICC is authorized, either upon complaint or sua sponte, to conduct a hearing. ${ }^{12}$ Pending hearing and decision, the Commission may suspend the proposed change for a period of time not to exceed seven months beyond the time when the rate would have gone into effect. The ICC must give reasons for its suspension. If the proceeding is not completed within this period, the carrier may put the change into effect. The Commission, however, may require, in the case of an increased rate for transportation of property, that the carrier maintain records of amounts collected by reason of such increase and that it refund, with interest, any portion ultimately found to be unjustified. The statute further provides that suspension cases shall be given priority and that the burden of justifying proposed changes shall be upon the carrier. ${ }^{13}$

A failure by the Commission to suspend a rate change does not immunize a carrier from a subsequent investigation and appropriate

8 See text accompanying notes $225-33$ infra.

95 U.S.C. $\$ 556 \mathrm{~d}(1970)$.

10 Interstate Commerce Act $\S 6(3)$, 49 U.S.C. $\S 6(3)(1970)$, is the provision relating to rail carriers. Comparable provisions for other types of carriers appear in id. $\$ 317$ (c) (motor carriers); id. $\$ 906$ (d) (water carriers); id. $\$ 1005$ (d) (freight forwarders).

$11 I d . \S 6(3)$.

12 Id. $\S 15(7)$. Comparable provisions appear in id. $\$ \S 316(\mathrm{~g}), 907(\mathrm{~g}), 1006(\mathrm{e})$.

13 Id. $\$ 15(7)$. 
remedial proceedings. The Commission may at any time institute a proceeding to investigate existing rates and practices, either upon complaint or upon its own initiative. "Any person, firm . . . , assocation ... . organization . . . body politic . . . or common carrier" may file a complaint, and the Commission has a duty to investigate if there appears to be "any reasonable ground" for doing so. ${ }^{14}$ Under these procedures, however, the burden of proof falls upon the moving party rather than the carrier.

\section{A. An Historical Note}

The administrative power to suspend a rate pending investigation into its legality was fashioned in the context of railroad regulation. In later years, however, Congress consciously adopted the same design in other regulatory statutes. ${ }^{1 \overline{5}}$ Accordingly, the history of the Interstate Commerce Act illuminates the suspension power that is common to the various regulatory schemes to which this study is addressed. That history, as indicated below, supports the view that Congress intended to confide the power to delay the effectiveness of rate changes exclusively to administrative authority and that it regarded the exercise or nonexercise of that power as a matter fully committed to agency discretion.

Prior to the Mann-Elkins Act of $1910,{ }^{16}$ rates could be challenged only upon complaint and after they had gone into effect. The Commission came to regard this as a serious deficiency, particularly during a period of rapidly rising prices, and beginning in 1907 urged that it be accorded power to restrain proposed changes while they were under investigation. ${ }^{17}$ Some shippers, the Commission observed, had repaired to the courts in order to seek injunctive relief pending a Commission hearing, and this was unsatisfactory on several grounds. ${ }^{18}$ The courts,

$14 I d . \$ 13(1)$. Comparable provisions appear in id. $\$ \$ 304(\mathrm{c}), 907$ (a), 1006(a).

In addition to seeking prospective relief, the private complainant may also seek an administrative award of reparations for injuries inflicted by a rail or water carrier. See id. $\$ \$ 16(1), 908(d)$. If the complaint is filed against a motor carrier or freight forwarder, the Commission may grant only prospective relief. In order to recover damages the complainant must proceed by an action at law. See id. $\$ \$ 304 a, 1006$ a.

15 E.g., Natural Gas Act $\S 4(\mathrm{e}), 15$ U.S.C. $\$ 717$ c(e) (1970) ; Federal Power Act $\$ 205(\mathrm{e}), 16$ U.S.C. \$ 824d (e) (1970); Federal Communications Act $\$ 204,47$ U.S.C. $\$ 204$ (1970); Motor Carrier Act $\$ 216(\mathrm{~g}), 218(\mathrm{c}), 49$ U.S.C. $\$ \$ 316(\mathrm{~g})$, 318(c) (1970); Water Carrier Act $\$ 201$, 49 U.S.C. $\$ \$ 907(\mathrm{~g})$, (i) (1970) ; Freight Forwarders Act $\$ 406(\mathrm{e}), 49$ U.S.C. $\$ 1006(\mathrm{e})(1970)$; Federal Aviation Act $\$ 1002$, 49 U.S.C. $\$ 1482(\mathrm{~g})$ (1970). See also Intercoastal Shipping Act, 46 U.S.C. $\$ 845$ (1970).

16 Act of June 18, 1910, ch. 309, 36 Stat. 539.

171 I. Sharfman, The Interstate Commerce Commission 49-52 (1931); 21 ICC ANN. REP. 9-10 (1907); 22 ICC ANN. ReP. 10-12 (1908); 23 ICC ANN. Rep. 6-7 (1909),

1823 ICC Ann. Rep. 6-7 (1909). 
for one thing, were in disagreement as to their power to consider charges of illegality that were appropriate for decision in the first instance by the Commission. ${ }^{19}$ Moreover, the exercise of jurisdiction by those courts that assumed the power to act had frequently led to confusion and discrimination. Carriers in some instances were required to maintain one rate in their published tariffs and to collect another. If all affected shippers failed to join in the injunctive suit, judicial relief might run to the complainants but not to other members of the shipping public. Further complications arose in the case of joint rates because the plaintiffs might secure jurisdiction over only one of the participating carriers. Courts often required the posting of substantial bonds as a precondition to injunctive relief. The judicial remedy was seen not only as dubious and inadequate but as repugnant to the Commission's role as the primary and expert arbiter of rate disputes.

Early in 1910, President Taft submitted to Congress his recommendations for improved regulation of rail carriers, which included a proposal that the Commission be "empowered, in its discretion, to postpone the effective date of a rate increase for a period not exceeding sixty days . . . . 20 During the protracted legislative proceedings that followed, a focal issue was the length of the suspension period, with the Administration continuing to favor a relatively short period and various insurgents contending that suspension of rate increases should last until the ICC completes its formal investigation. ${ }^{21}$ The resulting compromise authorized the Commission to suspend for a period of up to 120 days and, if the hearing could not be concluded within that time, for a further period not exceeding six months. ${ }^{22}$

Significantly, throughout the period during which the amendments were considered there seems to have been no departure from the assumption that the Commission would have an unfettered discretion to determine whether the situation warranted the exercise of the power to suspend. The representative of the National Industrial Traffic League, the chief organization of the country's shippers, urged that the Commission, drawing upon its experience and information, should be permitted to suspend a rate advance "in its discretion, upon a prima facie showing," so that "chaos and harassing litigation may be

19 The Supreme Court later expressed its approval of those decisions of the lower federal courts that disclaimed jurisdiction. Board of R.R. Comm'rs v. Great N. Ry., 281 U.S. 412, 429 (1930).

2045 Cong. REC. 462 (1910).

21 See 45 Cong. Rec. 6409, 6500-01, 6510-11, 6900-01 (1910). Under the Taft proposal, rate changes other than increases would have been subject to suspension for a limited period.

22 Mann-Elkins Act $\S 12$, ch. 309, §12, 36 Stat. 552 (1910). 
avoided." ${ }^{23}$ The report of the Senate Committee on Interstate Commerce states that the Commission "should, in its discretion, be empowered . . . to postpone . . the effective date . . . for a reasonable period to enable it to investigate the proposed action." 24 Senator Cummins, a member of the Committee, explained that the proposed change would enable the Commission to issue "what lawyers will understand to be in the nature of a preliminary injunction suspending . . . such rates as it cares to suspend or desires to suspend from going into effect . . . ." 25 Senator Elkins, a principal sponsor of the legislation, likewise explained that the bill would confer "the discretionary power to suspend." 26

The legislative history also lends support to the view that the "injunctive" power accorded the Commission was designed as a substitute for any equitable powers that the courts might possess, rather than as a supplement to those powers. As observed above, the President's recommendation that Congress authorize an administrative power to suspend was responsive to the Commission's expressed concern that resort to the courts had proved troublesome. The National Industrial Traffic League echoed the suggestion that the Commission was "better able to determine the equities of the case than the courts, their entire study being one of transportation." 27 Comments of influential legislators indicate, moreover, that the arguments as to the appropriate length of the suspension period were premised upon the assumption that when the period expired there would be no obstacle to putting the rates into effect even though the Commission's investigation might be uncompleted. $^{28}$ Proponents of a short period of suspension argued that prolonged delay would be unfair to the railroads, as they could not recover losses incurred during the period of suspension even though an increased rate might ultimately be approved. ${ }^{29}$ Those who contended for a longer period warned of shifting an undue share of the burden to the public. ${ }^{30}$ Neither group, it would appear, contemplated that when the period of suspension terminated, the question of interim relief might simply be shifted to the courts. During consideration of

23 Hearings on Bills Affecting Interstate Commerce Before the Honse Interstate \& Foreign Commerce Comm., 61st Cong., 2d Sess. 437 (1910) (testimony of James C. Lincoln).

24 Senate Coamm. on Interstate Comarerce, Court of Conmerce, S. Rep. No. 355, 61st Cong., $2 d$ Sess., pt. 1 , at 9 (1910).

2545 CONG. REc. 6500 (1910).

2645 CoNG. REc. 3472 (1910).

27 Hearings on Bills Affecting Interstate Conmerce Before the House Interstate \& Foreign Commerce Comm., 61st Cong., 2d Sess. 438 (1910). See also id. 445.

28 See 45 Cong. REc. 6782-83, 6787, 6916-17, 8370, 8387 (1910).

2945 Cong. Rec. 3472, 4109-10, 6503, 6509, 6782, 6787-88 (1910).

3045 CoNG. REC. 3373-75, 6500-01, 6510-11, 6900-01 (1910). 
those provisions of Mann-Elkins that created the short-lived Commerce Court, Senator La Follette did offer an amendment that would have permitted that court, in certain circumstances, to enjoin rate changes pending a final determination by the ICC. That amendment, however, was defeated. ${ }^{31}$

In the comprehensive Transportation Act of 1920, two changes were made in the existing provisions for tariff suspension. If a carrier put an increased freight rate into effect after expiration of the suspension period, but before the conclusion of the Commission's investigation, the ICC was authorized to order it to keep account of all amounts collected by reason of the increase and to refund with interest the portion of the increase found not justified. Congress also reduced from ten months to five months the maximum period for which the Commission might suspend. ${ }^{32}$ In 1927, the Commission informed Congress of its inability to make the necessary investigation and determination of rate cases within the five-month suspension period, and Congress responded by lengthening the maximum permissible period to seven months, the point at which it currently stands. ${ }^{33}$

Neither the history of the 1920 act nor that of the 1927 act provides any basis for altering the conclusion derived from the examination of the Mann-Elkins Act that the decision whether to suspend a given tariff was intended to be exclusively an administrative prerogative, discretionary with the Commission.

The main course of judicial decisions points the same way. It has been definitively settled that the courts have no independent authority to delay the effective date of a change in rates and that the only injunctive power is that delegated to the agency. ${ }^{34}$ The cases uniformly support the proposition that the agency's initial determination to suspend or refrain from suspending is ordinarily unreviewable. ${ }^{35}$ There

3145 CoNg. Rec. 7260-64 (1910).

32 Ch. 91, tit. IV, $\$ 418,41$ Stat. 487 (1920).

3349 U.S.C. $\$ 15(7)(1970)$.

34 Arrow Transp. Co. v. Southern Ry., 372 U.S. 658 (1963). In Arrow the railroads had substantially reduced rates on grain, and the Commission had suspended them for the maximum statutory period. When the ICC failed to reach a decision within the 7-month period and the 5 succeeding months (during which the rail carriers voluntarily refrained from putting them into effect), the railroads announced that they would proceed to put the proposed rates into effect. A competing barge line thereupon sought injunctive relief from a federal district court, alleging that if the new grain rates were put into effect, it would be driven from business before the Commission concluded its inquiry into their validity. Affirming the decisions of the lower courts, the Supreme Court ruled (3 Justices dissenting) that $\$ 15(7)$ of the Act conferred upon the Commission the sole and exclusive power to suspend the operation of new rates.

35 Cincinnati, N.O. \& T.P. Ry. v. Chesapeake \& O. Ry., 441 F.2d 483 (4th Cir. 1971) ; National Indus. Traffic League v. United States, 287 F. Supp. 129 (D.D.C. 1968), aff'd per curiam, 393 U.S. 535 (1969); Movers \& Warehousemen's Ass'n v. United States, 227 F. Supp. 249 (D.D.C. 1964); Long Is. R.R. v. United States, 
has been a difference of opinion, however, on the question whether a Commission order vacating a previous suspension may be judicially examined for abuse of discretion. ${ }^{36}$ Moreover, there has been some recent intimation that courts may look upon certain exercises of the suspensory power as sufficiently extraordinary to warrant intervention. ${ }^{37}$

\section{B. Procedure}

The ICC has had long experience with the power of suspension, and, dealing with an immense volume of tariff publications annually, ${ }^{38}$ it provides a principal source of data for appraisal of the suspension process. Before turning to a consideration of performance and results, it will be useful to outline briefly the ICC suspension procedures.

193 F. Supp. 795 (E.D.N.Y. 1961) ; Luckenbach S.S. Co. v. United States, 179 F. Supp. 605 (D. Del. 1959), vacated as moot, 364 U.S. 280 (1960); National Water Carriers Ass'n v. United States, 126 F. Supp. 87 (S.D.N.Y. 1954); Carlsen v. United States, 107 F. Supp. 398 (S.D.N.Y. 1952); Algoma Coal \& Coke Co. v. United States, 11 F. Supp. 487 (E.D. Va. 1935); M. C. Kiser Co. v. Central of Ga. Ry., 236 F. 573 (S.D. Ga. 1916), aff'd, 239 F. 718 (5th Cir. 1917); see Municipal Light Boards v. FPC, 40 U.S.L.W. 2243 (D.C. Cir. Oct. 14, 1971) (agency's decision to suspend a major rate increase for 1 day, rather than the full 5 months allowed by the Federal Power Act, is an unreviewable exercise of discretion).

As some of these decisions point out (especially Long Is. R.R. v. United States, 193 F. Supp. 795, 799-800 (E.D.N.Y. 1961)), a quite different question would be presented if the case were one in which the agency had failed to follow a clear statutory command or limitation, e.g., had suspended for a period beyond the permitted 7 months. Similarly, Ferguson-Steere Motor Co. v. United States, $126 \mathrm{~F}$. Supp. 588 (N.D. Tex. 1954), indicates that an order to suspend would be defective if unaccompanied by a statement of reasons, but holds that the court will not look behind a "boiler plate" statement of reasons.

36 Amarillo-Borger Express, Inc. v. United States, 138 F. Supp. 411 (N.D. Tex. 1956), vacated as moot, 352 U.S. 1028 (1957), holds that once the agency has made an explicit determination that a rate should be suspended, it may not reverse that determination on reconsideration without providing an adequate explanation. Accord, Atlantic Coast Line R.R. v. United States, 173 F. Supp. 871 (E.D. Va. 1958) ; Dixie Carriers, Inc. v. United States, 143 F. Supp. 844 (S.D. Tex. 1956), vacated as moot, 355 U.S. 179 (1957) ; Iong Is. R.R. v. United States, 140 F. Supp. 823 (E.D.N.Y. 1956). Other courts have refused to follow Amarillo-Borger, reasoning that a vacation of a suspension order after reconsideration is not unlike a refusal to suspend in the first instance. See, e.g., Naph-Sol Ref. Co. v. United States, 269 F. Supp. 530 (W.D. Mich. 1967); Oscar Mayer \& Co. v. United States, 268 F. Supp. 977 (W.D. Wis. 1967) ; Freeport Sulphur Co. v. United States, 199 F. Supp. 913 (S.D.N.Y. 1961).

Clearly there is a much stronger basis for judicial review when an agency's decision to terminate the rate proceeding takes place at a more advanced stage, e.g., after a hearing before an examiner has been conducted. See Wisconsin v. FPC, 373 U.S. 294 (1963) ; Minneapolis Gas Co. v. FPC, 294 F.2d 212 (D.C. Cir. 1961). In such circumstances, the Supreme Court declared that "the issue is whether the termination constituted an abuse of discretion ...." Wisconsin v. FPC, 373 U.S. 294, 308 (1963).

37 See text accompanying notes 155-80 infra for a discussion of Moss v. CAB, 430 F.2d 891 (D.C. Cir. 1970).

38 A tariff publication may consist of a single page or run to hundreds of pages. Some contain rates, rules and regulations affecting the rates, and the measure of service provided thereunder. Others are free of rate quotations, containing only rules and regulations, classification ratings, and routing and other provisions that govern the rate tariffs. One or more of the tariff adjustments contained in a tariff publication may be considered for suspension. 
Since 1952 the Commission has delegated to a board of employees, the Suspension Board, authority to make the initial determination. ${ }^{39}$ When a tariff change is filed, the Board, which consists of five members ${ }^{40}$ and has a supporting staff, ${ }^{41}$ may enter an order of investigation and suspension, initiate an investigation without suspension, or decline to take action.

As observed above, a tariff publication must be filed thirty days before the proposed effective date. Of necessity, therefore, the Board must do its screening rapidly. In practice, it devotes almost all of its attention to those tariff filings eliciting protest from shippers or competing carriers. ${ }^{42}$ Under the Commission's rules, protests and requests for suspension normally must be filed with the Commission and served upon the publishing carrier no less than twelve days before the effective date of the tariff. ${ }^{43}$ The protestant is called upon to specify the basis of his objection and to indicate what he would consider a satisfactory alternative. ${ }^{44}$ The protest is regarded as one "addressed to the discretion of the Commission," and is not deemed a formal complaint. ${ }^{45}$ The carrier may submit a reply, but must file and serve it at least three full workdays prior to the effective date of the rate change to assure its consideration by the Board. The Board normally votes three days in advance of the effective date.

Proceedings before the Board are "informal;" 46 no subpoenas will be issued, nor will a transcript be made. ${ }^{47}$ If the Board declines to suspend a proposed tariff change, the protestants may seek reconsideration of the decision by Division Two of the Commission. ${ }^{48}$ This request must reach the Commission no later than two workdays prior to the effective date of the protested matter. ${ }^{49}$ When the Board votes to sus-

39 The delegation was made pursuant to $\S 17(2)$ of the Interstate Commerce Act, 49 U.S.C. $\$ 17(2)(1970)$.

40 The members of the Board have had extensive experience in transportation matters, in both private and public employment. They are not lawyers.

41 At present, the supporting staff consists of 34 employees, including clerical personnel. At one time, the staff was approximately $25 \%$ larger.

42 See text following note 62 infra.

4349 C.F.R. \$1100.42 (1971) (Comm'n Rule 42). If the Commission has granted the carrier leave to file a change on less than 30 days notice, the protest must be received not less than 5 days prior to the effective date. Telegraphic protests are permitted. $I d$.

$44 I d$.

$45 I d$. The rules further declare that if a protestant desires to "proceed further against a tariff or schedule which is not suspended, or which has been suspended and the suspension vacated, a separate later formal complaint or petition should be filed." Id.

$46 I d . \S 1100.200$ (a).

$47 I d$.

48 Division 2 has been designated the appellate division for all matters relating to suspension. Id. $\$ 1100.200(\mathrm{~b})$.

49 Id. $\$ 1100.200(\mathrm{c})$. 
pend, however, the time requirements are less stringent. The affected carrier may file a petition to vacate the order within twenty days. ${ }^{50}$ This period also applies to petitions seeking reconsideration of a Division Two order altering a decision of the Suspension Board. ${ }^{51}$

\section{The System in Operation}

Performance is in part a function of volume. In fiscal 1970 more than 300,000 tariffs were filed with the ICC, a fifty-percent increase over comparable figures of a decade earlier. Approximately ninety-five percent of these were freight tariffs; passenger and express traffic accounted for the balance. Of the freight tariffs, more than 193,000 were filed by motor carriers (common and contract), and upward of 81,000 by rail carriers. The remainder comprised approximately 11,000 filings by freight forwarders, 3000 by water carriers, and 1100 by pipelines. ${ }^{.2}$

In the same year, the Commission considered for possible suspension some 4088 "tariff adjustments." An adjustment, in the Commission's lexicon, is any change in one or more tariffs that raises a discrete issue. $^{53}$ Of the 4088 adjustments, ${ }^{54}$ the ICC considered only 259, slightly more than six percent, on its own initiative. The remaining 3829 cases resulted from the filing of protests. ${ }^{\tilde{5} 5}$ The adjustments in question were reflected in 11,137 tariff publications (one adjustment may appear in several publications of the carrier or its traffic agent). Comparing the latter figure to the more than 300,000 tariff publications filed that year, it appears that an average of only one in twenty-eight was considered by the Commission for suspension. ${ }^{56}$

The action taken in fiscal 1970 on adjustments involved in the Commission's deliberations is shown by the following table.

50 Id. $\$ 1100.200$ (b) (1).

51 Id. $\$ 1100.200$ (b) (3).

52 The statistical picture for the past decade (fiscal years 1961-1970 inclusive) is set forth in Appendix A. For these and most of the other data set forth in this section, the author is indebted to the ICC's staff and particularly Mr. George Filton of the Suspension Board.

53 Thus, if in connection with a single commodity, a carrier proposed a 5\% increase in the charge for carriage, and modifications of the relevant minimum and detention charges, there would be 3 adjustments appropriate for Commission consideration. A carrier-proposed $5 \%$ general increase in all its existing rates would constitute 1 adjustment.

54 These adjustments involved 525 changes by rail carriers, 3394 by motor carriers, 58 by water carriers, 96 by freight forwarders, and 15 by express and pipeline companies. Statistics for the fiscal years 1961-1970 inclusive are set out in Appendix B.

55 See 84 ICC Ann. Rep. $41-42$ (1970).

56 Data for the full decade 1961-1970 are shown in Appendix C. As indicated therein, the percentage of tariff publications considered for suspension ranged from $2.5 \%$ to $4.5 \%$ of the total number of publications. 
TABLE $I^{57}$

Disposition of Adjustments Considered by the ICC

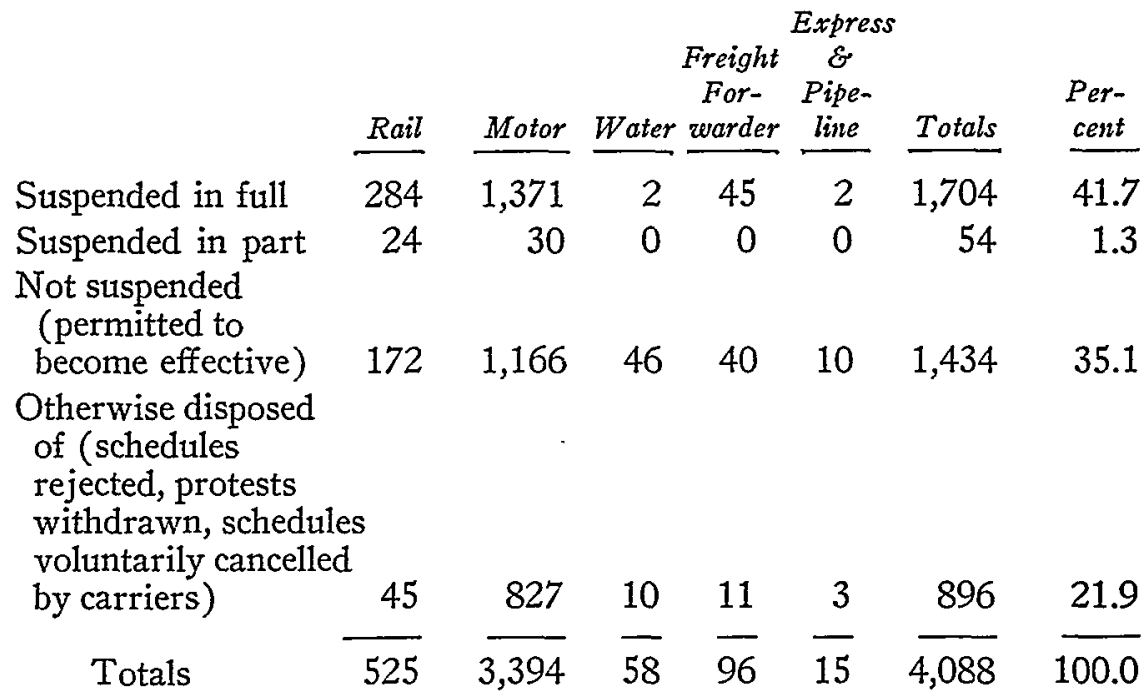

As may be noted, 896 proposals were disposed of prior to their effective date and in advance of action by the Commission. Almost half of these were withdrawn by the carriers. ${ }^{58}$

The ICC does not maintain statistics summarizing the results of cases in which it has decided that a formal investigation is warranted. A survey conducted approximately a decade ago, however, showed that during a twelve-month period, a decision on the merits was required in only seventeen percent of the cases (285 of 1663 "investigation and suspension" proceedings). ${ }^{59}$ In the remainder, the suspended rate was withdrawn, or the carrier failed to defend it at a hearing. In more than two-thirds of the contested cases, the Commission determined that the challenged adjustment was unlawful in whole or in part. Thus, in well over ninety percent of the cases in which the Commission exercised its

5784 ICC ANn. REP. 41 (1970).

Of the 4088 adjustments considered by the ICC, 2062 involved increases, 1774 reductions, 194 both increases and reductions, and 58 neither one. Protests numbered 5038: 3454 were from shippers and receivers, 1518 from competing carriers, and 66 from government agencies. Id.

Actions taken on adjustments considered for suspension during the years 19611969 are shown in Appendix B. Data respecting protests filed in those years appear in Appendix D. $\mathrm{E}$.

58 The number of voluntary cancellations per calendar year is shown in Appendix

59 The survey discussed in the text was conducted in connection with an unpublished study of ICC rate proceedings made by Professor Roger C. Cramton in 1961 for the Committee on Rulemaking of the Administrative Conference of the United States. 
suspension power, the carrier's proposal was ultimately abandoned or disapproved. ${ }^{60}$

Two recent samplings of suspended rates made in conjunction with the present study ${ }^{61}$ and summarized in the following tables indicate that the picture is substantially unchanged. They show that a substantial majority of the proceedings never reach the hearing stage, and that only a small fraction of those adjustments suspended by the Commission take effect as proposed.

\section{TABLE II}

Disposition of Motor Investigation and Suspension Proceedings

Instituted in the Period From December 20, 1968, Through February 4, 1969

Suspension vacated and schedules permitted to become effective without hearing .............. 1

After hearing, tariff found not unlawful and permitted to become effective .................. 3

After hearing, tariff found not just and reasonable and required to be cancelled ............... 7

Tariff voluntarily cancelled by carriers prior to hearing or ordered to be cancelled because of failure to defend at hearing $\ldots \ldots \ldots \ldots \ldots \ldots \ldots . . . \ldots 9$

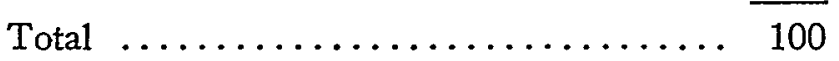

\section{TABLE III}

Disposition of RaId, Water, Freight Forwarder, Express, and Pipeline Investigation and Suspenston Proceedings Instituted in the Period From November 26, 1968, Through September 20, 1969

Suspension vacated and schedules permitted to become effective without hearing ............... 7

After hearing, tariff found not unlawful and permitted to become effective .................. 2

After hearing, tariff found not just and reasonable and required to be cancelled ............... 8

Tariff voluntarily cancelled by carriers prior to hearing or ordered to be cancelled because of failure to defend at hearing $\ldots \ldots \ldots \ldots \ldots \ldots \ldots \ldots \ldots, 33$

Total $\ldots \ldots \ldots \ldots \ldots \ldots \ldots \ldots \ldots, 50$

${ }^{80} \mathrm{Id}$.

61 Based upon an examination of Suspension Board files. 
As is evident from the preceding discussion and the supporting appendices, ${ }^{62}$ in a typical year ninety-six to ninety-seven percent of the tariff publications filed with the ICC become effective by virtue of nothing more than the passage of time. Only three to four percent are characteristically involved in those adjustments considered for suspension. Members of the Suspension Board acknowledge that their attention is devoted almost exclusively to those items that have generated a protest. It is true that in 1970 the Board considered sua sponte 259 adjustments - of a total of 4088 considered. These 259 , however, were the product of a routine and cursory examination of certain tariffs that had as its sole object spotting those publications containing one of several species of restrictive provisions regarded as prima facie discriminatory. ${ }^{63}$ Apart from this limited category, the prospect that a tariff will be considered for suspension has depended entirely upon the likelihood of an initiative from outside the Commission.

Question immediately arises as to the extent an agency can rely upon the self-interest of those entitled to protest as a device for alerting it to those matters that warrant its consideration. Certainly, tariff changes that have a broad impact upon commercial interests will rarely escape the prompt attention of shippers, receivers, and competing carriers. Results are less certain, however, where the adjustment is of a lesser order. The adverse effects of a minor adjustment may be confined to a limited number of small shippers. Unless these shippers patronize a watching service or are members of a shippers' organization that maintains a watch on tariff publications, they may learn of a tariff change that has significant consequences for them only after it has taken effect. At that point the forces of inertia are heavily with the carrier, as the burden has shifted to the shippers. They can force the issue only if prepared to file a formal complaint and to incur the costs involved in presenting an evidentiary case challenging the legality of the new rate. ${ }^{6 t}$ That is rare.

Even if one assumes, as the Commission implicitly does, that commercial interests will alert it to those changes in freight tariffs that warrant scrutiny, a further question is presented with respect to tariff changes affecting passengers. A check reveals that, when the change

62 See Appendices A, B.

63 Four or 5 employees are engaged in this screening process, which was instituted in 1967 at the suggestion of Commissioner Walrath, Chairman of Division 2. When the Suspension Board encounters one of the suspect provisions, it requests the carrier to submit a justification. (Based upon conversation with Suspension Board members.)

64 Although the Commission can initiate a proceeding in its own right, it is apt to respond to a suggestion that it do so only when the matter has obvious and general importance. Ordinarily, it will remit the party to his option of filing and pursuing a formal complaint. 
is one affecting commuter service by rail or motor, protests are regularly filed, and the matter is considered for suspension. ${ }^{65}$ In the case of tariff changes affecting long-haul passenger service, however, the response is sporadic. Apparently in that area the economic effect upon individuals is too diluted to stimulate the effort.

Of those adjustments that the Commission actually considers for suspension, how adequate is the information upon which it acts, and what standards does it employ? Carriers and protestants frequently provide little more than conclusory statements by way of justification or objection. Perhaps this is not surprising in view of the large number of changes that are constantly being made in the rate structure for competitive and other reasons. The Suspension Board does seek to encourage more pointed presentation and the submission of relevant data, but with small success. The combination of heavy volume and wide variety makes it difficult to prescribe standardized requirements and forms, and, for the most part, little has been attempted along these lines. ${ }^{66}$ The Board does, of course, make some use of the facilities and data of the Commission. ${ }^{67}$ Moreover, Board personnel sometimes discuss the matter informally (usually by telephone) with the carrier or its agent and obtain added information in that way. A conversation can pinpoint the area of the Board's concern, and it is reasonable to assume that on occasion it prompts a withdrawal and the filing of a modified substitute. $^{68}$ It appears, however, that members of the Suspension

65 Protests are commonly received from individual commuters, commuter groups and organizations, and towns and cities. (Based upon conversation with Suspension Board members.)

66 A recent exception should be noted. On April 7, 1971, the Commission issued an order prescribing new procedures applicable to the filing of general increases by designated tariff publishing agencies (rate bureaus) on behalf of their motor commoncarrier members. Details, including various limitations upon the application of these requirements, are set forth in Ex Parte No. MC-82, New Procedures in Motor Carrier Revenue Proceedings, 339 I.C.C. 324 (1971). For present purposes, it suffices to say that the object is to require the affected rate proponents to submit, in a convenient and uniform way, the cost and traffic data that the Commission regards as necessary to an expeditious and informed judgment whether the proposal is justified. The detailed requirements have not been made more widely applicable because of the recognition that their satisfaction would entail substantial cost.

67 For example, in a case involving an increase by an individual carrier, the Board might seek information from the Commission's cost-finding section concerning the relevant territorial averages.

68 On very rare occasions, Division 2 of the Commission has entered a "speaking" order of suspension, i.e., one that invites a modified substitute. An example is an order entered in Increased Rates and Charges, Middle Atlantic Conference, Interstate Commerce Comm'n, I. \& S. Docket No. m-24549, Dec. 31, 1970, in which the Commission first suspended various $8 \%$ rate increases but then added:

It is further ordered, That respondents be, and they are hereby, author-

ized to establish upon not less than 1 day's notice in lieu of the suspended

rates and charges, new increase in rates and charges of six percent applied

in the same manner as the increases suspended herein . . . .

For another example, see Increased Rates and Charges, The Alaska Railroad, Interstate Commerce Comm'n, I. \& S. Docket No. 8604 (Sub No. 1), Order of Mar. 15, 
Board do not regard it as their function to suggest modifications to the carriers or to seek settlement of disputed matters by inviting those carriers to withdraw their proposals and to file substitutes.

In sum, it seems fairly evident from files and from statements of Board members that the Board, heavily pressed by the volume of business and the restraints of a tight schedule, is often required to act on information that is sketchy at best. In these circumstances, the Board almost inevitably tends to place substantial reliance upon its "feel" for the matter and its sense of the Commission's preferences and predispositions on issues of transportation policy. ${ }^{69}$

The nominal test to which the Suspension Board and Division Two subscribe is that which is customary among the regulatory agencies: whether there is probable cause to believe that the proposal, if made effective, would violate the Act. ${ }^{70}$ Suspension orders of the ICC do not attempt to articulate the reasoning that leads to the conclusion that a violation would probably result. The statement of reasons is invariably a paraphrase of the statute ${ }^{71}$-for example, that schedules appear to be unjust and unreasonable, in violation of the Interstate Commerce Act; unjust and unreasonable, in violation of the Interstate Commerce Act, and constitute unfair and competitive practices in contravention of the national transportation policy; unduly prejudicial and preferential, in violation of the Interstate Commerce Act; or unjustly discriminatory, in violation of the Interstate Commerce Act. ${ }^{72}$ To ascertain what lies behind such generalizations, the affected parties

1971. Cf. Algoma Coal \& Coke Co. v. United States, 11 F. Supp. 487 (E.D. Va. 1935); Birmingham Slag Co. v. United States, 11 F. Supp. 486 (N.D. Ala. 1935). The use of similar technique is discussed more fully in text accompanying notes 155-80 infra.

69 When it considers an appeal from a refusal to suspend, Division 2 ordinarily acts on the information gathered by the Board. According to the sampling of 1500 suspension actions taken in 1960-1961, note 59 supra, protestants appeal in approximately one-third of the cases in which the Board declines to act.

In instances in which a carrier petitions Division 2 for reconsideration of a previous suspension, the Division is apt to have the benefit of some argument and information that it did not have when it first acted. As shown by the discussion above, text accompanying notes 45-49 supra, there is only a 3-day interval between a Board decision to refuse suspension and the Division's determination of an appeal from that determination. Petitions to vacate a suspension, however, are timely if filed within 20 days; thus there is more time to supplement the file. Petitions to vacate are filed in approximately one-tenth of the cases in which a rate investigation is ordered.

One further datum from Professor Cramton's 1960-1961 sampling is of interest. Division 2 disagreed with the Suspension Board, in whole or in part, in almost $30 \%$ of the cases in which there was an appeal from an order refusing to suspend, or a petition to vacate a suspension order. The percentages were roughly the same in both categories of determinations.

70 The statute does not require any statement when suspension is declined, and none is issued.

71 This is equally true whether the action is that of the Board or Division 2.

72 Based upon examination of Suspension Board files. 
can do no better than read Commission decisions in formal casesthemselves not always notable for their clarity-and indulge in moreor less-informed speculation.

As appears from Table $I$ above, ${ }^{73}$ in more than half the cases that came to a vote ${ }^{74}$ in fiscal 1970 the result was an order of suspension. ${ }^{75}$ Most suspended schedules, however, are voluntarily withdrawn by the carrier or are ordered cancelled because of the carrier's failure to defend at a hearing. ${ }^{78}$ In a striking proportion of the cases, when the Commission exercises its summary power to suspend pending formal investigation, an investigation never takes place and litigation is avoided.

There are several explanations for this. In some instances, the proposed change is rather unimportant from the carrier's point of view. The publication may be one filed primarily to accommodate a particular shipper, and its acceptance or rejection by the Commission may be of little moment to the carrier. ${ }^{77}$ In other instances, the proposal may be one designed to serve a short-run purpose; a suspension automatically defeats that objective. Finally, and most importantly, the proponent of a change must weigh two factors against the gain that he anticipates would result if the proposal were put into effect: the costs of presenting a formal case and the chances of a favorable decision on the merits in the face of an agency finding of probable cause to suspend. This calculus will often lead to the conclusion that the odds are unfavorable and that it would be better to try another tack.

\section{Conclusions and Recommendations}

It may well be, as more than a few critics have urged, that the scope of regulation of surface transportation should be drastically narrowed, and the standards and objectives redefined. This Article, however, is directed to the Commission's use of specified powers within the

73 Table in text accompanying note 57 supra.

74 Typically, about $10 \%$ of the adjustments that come under consideration are voluntarily withdrawn in advance of action by the Suspension Board. See Appendix E. Roughly an equal number may fail to reach the voting stage because the schedule is rejected for a legal defect or because the protest is withdrawn. See id.

75 For the entire decade 1961-1970, it appears that slightly more than one-half of the adjustments voted upon were suspended. See grand totals set forth in Appendix $B$. The difference between 1970 and the average for the preceding 9 years is accounted for largely by the high rate of suspension in rail cases in 1970 (284 suspended, 172 not suspended). In the years 1961-1969, the rate was far lower. It has been consistently high in motor carrier cases, in which the number "suspended" exceeded the number "not suspended" in every year of the decade except 1966, when the figures in the 2 categories were fairly close. Appendix $B$.

76 Tables in text following note 61 supra.

77 In some instances publications are withdrawn upon the filing of a protest without the carrier even awaiting action by the Suspension Board. Some of these are matters that are doubtless of small concern to the carrier. 
framework of its existing regulatory responsibilities. Given that premise, it is apparent that the Commission must continue to rely heavily upon the initiative of protestants in exercising its authority to suspend and investigate. A thorough examination of all of the tariff publications filed annually with the ICC would require a staff of experts and factfinders many times the size of the staff now devoted to those matters. There is little reason to favor such an expansion of administrative activity. The self-interest of competitive carriers and of receivers and shippers provides adequate incentive to bring to the agency's attention most of those matters that warrant its serious consideration. So viewed, the problem is one of identifying and addressing the limitations and deficiencies.

Two weaknesses have been noted. The system does not work well when the impact of particular tariff adjustments is largely confined to small and unorganized shippers who are apt to learn of the adverse effects only after the rates have become effective. The imperfections of the system are also evident in the field of long-haul passenger service: those affected are unorganized, and their economic interest as individuals is small even though that interest is far from insubstantial in the aggregate.

An increased degree of self-organization by such groups is a theoretical possibility but one not easily achieved, and the Commission is ill-equipped to promote such a development. It is, however, specifically empowered for good cause to modify statutory requirements "in respect to publishing, posting and filing of tariffs . . . ." 78 It could require public notification by means more efficacious than mere filing of the change with the Commission. For example, the agency might fashion a rule requiring that in specified classes of cases the carrier publish notice, in summary form, in one or more newspapers having general circulation in the relevant geographic area.

Beyond this, the Commission should assume a greater burden of screening proposals in circumstances in which experience has shown that outside intervention is undependable. This would, indeed, require additions to staff personnel, but hardly on an inordinate scale. In light of the responsibilities with which it is charged, the ICC now does remarkably little on its own initiative. Five employees are currently engaged-and they not uninterruptedly-in checking tariff publications to ascertain whether they contain one of several types of restrictive provisions that the Commission regards as suspect. This is an absurdly meager undertaking when one considers that the Commission is charged with oversight of the rates of rail carriers, motor carriers, water car-

7849 U.S.C. $\$ 6(3)(1970)$. 
riers, pipelines, and freight forwarders. A modest increase in the staff attached to the Suspension Board, perhaps twenty additional employees, would permit the agency to make reasonably adequate preliminary investigations in selected areas of its jurisdiction that are now largely ignored. $^{70}$ This examination would not be confined to a check for particular suspect provisions but would seek to ascertain, by the use of Commission resources and by appropriate inquiries, whether a proposal raises questions sufficiently serious to warrant further exploration by the Suspension Board.

If the first area of concern is the matter of identifying the proposed rate changes that call for consideration, the second is the task of gathering the relevant information and making a reasoned disposition. In this the pressures of time play a critical role. ${ }^{80} \mathrm{~A}$ ready but less-thansatisfactory answer to the problem posed by these often acute pressures would be to rewrite the statutory provisions governing exercise of the suspension power to provide for longer waiting periods-such as sixty, instead of thirty, days-before a change might be made effective. This would provide the agency with a better opportunity to decide whether the circumstances warranted the fairly drastic measure of imposing a prolonged suspension. To require a sixty-day wait in every case, however, is unnecessary and would impose a heavy cost. Flexibility is an important value from the standpoint of carriers and shippers alike. A doubling of the waiting period would make more rigid the pricing structure, which, as matters now stand, is widely regarded as sluggish in its responsiveness to market conditions. It would inhibit the noncontroversial change as well as the disputed one.

Nonetheless, in some instances the Commission now meets its deadline only by acting without the benefit of adequate information from the proponent and the protesting parties, through a deliberative process that has excessive components of haste and hunch. Although the decision whether to suspend is necessarily a summary one, and its

79 Numerous proposals looking to the creation of a consumers' advocate are now pending before Congress. E.g., H.R. 10,835, 92d Cong., 1st Sess. (1971). It is doubtful, however, that such an agency, if it were created, would be well-equipped to exercise the detailed surveillance that could be expected of an expert staff exclusively devoted to an examination of tariff publications of surface carriers. Members of the Commission's staff have ready access to all of the resources of the agency. A representative of consumers could, however, play an important role in the rate cases that go to formal hearing. This is especially true in ICC cases because the Commission does not ordinarily assign members of its staft to participate in the hearing process, but relies almost entirely upon private parties and intervenors to explore the issues raised by proposed rate changes.

It appears that this much may indeed occur. The House bill was passed in an amended form on October 14, see 117 CoNG. Rec. H 9558-82 (daily ed. Oct. 14, 1971), and sent to the Senate.

80 The tight schedule imposed upon the Board by the deadlines for filing protests and replies exacerbates the normal pressures. See text accompanying note 43 supra \& following note 45 supra. 
object is a determination of "probable cause" rather than a final adjudication, the effects of these preliminary determinations are far from negligible. A decision to suspend means not only that the effectuation of the proposal is substantially delayed; it also imposes the necessity of formal and costly proceedings. As earlier observed, a common consequence is abandonment of the proposal. On the other hand, a decision to refrain from suspending in a case in which the proposal actually calls for further scrutiny may have serious consequences for those dependent upon the carrier's service.

What is needed is a device that will leave the thirty-day waiting period intact for the run of cases, but will permit the agency to delay effectiveness for an additional brief period in those hard and exceptional cases in which it finds it cannot intelligently act without further investigation and deliberation. To this end, the agency should be empowered to issue a "stop" order delaying for a brief additional period-twenty days is suggested-the date when a tariff schedule would otherwise become effective. ${ }^{81}$ Such a stop order would reflect nothing more than an agency determination that it required more time to decide whether its power of suspension should be exercised. ${ }^{82}$ During the period covered by the stop order, the agency, the carrier, and other affected parties would have opportunity to focus on the matter at hand in a far more productive manner than is feasible under present procedures. ${ }^{83}$

The Interstate Commerce Act, as well as the various statutes modeled after it, ${ }^{84}$ requires that the Commission, when it suspends a schedule, note in the official record and deliver to the affected carrier

81 Arguably, such stop orders could be issued under existing statutory authority. 49 U.S.C. $\$ 6(3)$ (1970), which imposes the requirement that no change shall be made by a carrier on less than 30 days' notice, also contains the following language:

Provided, That the Commission may, in its discretion and for good cause shown, allow changes upon less than the notice herein specified, or modify the requirements of this section in respect to publishing, posting, and filing of tariffs, either in particular instances or by a general order applicable to special or peculiar circumstances or conditions . . . .

The Commission, however, has long interpreted this language to permit modifications of filing requirements for the purpose of shortening the notice period, but not as authorizing a lengthening of the period. This seems correct. Read in context and in light of a history that reflects a congressional purpose to place a fixed limit upon the period that the Commission might delay a carrier from effectuating a change, see text accompanying notes 15-37 supra, it is at least doubtful that the courts would uphold an administrative modification of the requirements of $\S 6(3)$ along the lines of the suggested stop order procedure. Caution would dictate a request for explicit statutory authorization. But see text accompanying note 96 infra (describing the recent action of the Federal Communications Commission, modifying the notice requirements imposed by the Communications Act).

82 If the power to suspend is likened to the power to grant a preliminary injunction, issuance of a stop order might be analogized to the issuance of a temporary restraining order.

83 The stringent time limitations now governing protests, replies, and agency action are discussed in text accompanying notes 43-51 supra.

84 Statutes cited note 15 supra \& accompanying text. 
"a statement in writing of its reasons for such suspension . . . ." 85 There is nothing in the relevant history to suggest that Congress contemplated judicial review of orders of suspension, and a great deal of evidence suggests the contrary. ${ }^{86}$ The fair inference is simply that Congress believed that there was some utility in having the Commission make known to the affected parties the reasons for its exercise of summary power. ${ }^{87}$ There would be a considerable practical gain if the Commission implemented this directive by stating its grounds in a way that was informative rather than ritualistic.

A tariff publication typically contains a number of elements. Commission dissatisfaction with one or more of these could lead to a decision to suspend. If the statement of reasons consists merely of a broad generalization, for example, that the schedule appears to be unjust and unreasonable, in violation of the Interstate Commerce Act, the carrier can only guess at the particular source of the Commission's concern. One practitioner who is legal counsel for a major carrier stated that his company would file substitute schedules ninety percent of the time, if it knew why its original proposals had been suspended..$^{88}$ Not knowing, the company often decides to drop a proposal altogether or, on occasion, to litigate the matter at a formal hearing. Asked whether he couldn't find out what was on the agency's mind by sounding out a member of the staff, his reply was that "they don't usually talk to us that freely."

If the Commission's orders of suspension would identify and explain, to the extent practicable, what it is that the agency finds objectionable, or potentially so, the proponent obviously would be in a much better position to respond: to abandon the proposal, or particular features of it; to withdraw the pending proposal and submit an appropriately modified version that might pass muster; or to go forward with an awareness of the issue or issues that would have to be litigated

8549 U.S.C. $\$ \S 15(7), 316(\mathrm{~g}), 907(\mathrm{~g}), 1006(\mathrm{e})$ (1970).

86 Text accompanying notes $15-37$ supra.

87 The legislative history provides little direct evidence of Congress' purpose in requiring a statement of reasons. One of the principal witnesses at the hearings, the representative of the National Industrial Traffic League, did express the view that, during a period of suspension, modifications of the carrier's proposal might be worked out, "possibly with the advice and aid of the Commission in bringing out the facts." Hearings on Bills Affecting Interstate Commerce Before the House Interstate \& Foreign Commerce Comm., 61st Cong., 2d Sess. 444 (1910). Representative Townsend, sponsor of the administration's bill in the House, explained the language calling for a statement of reasons by analogizing it to the requirement that courts set forth their reasons for issuing restraining orders and temporary injunctions, apparently believing that it would serve a notice-giving function. Id. 439.

88 Based upon personal interviews by the author of individuals who do not wish to be identified. (Not all practitioners interviewed put the point that strongly, but none doubted the general validity of the observation.) 
to the agency's satisfaction. ${ }^{89}$ To be sure, specificity requires more of an effort, and there are limits to what one can reasonably expect from a summary process. An agency engaged in determining preliminarily whether it ought to maintain the status quo pending the conduct of a further proceeding, is not yet prepared to make detailed findings on the merits. Yet it is not unreasonable to ask for something more than a standardized paraphrase of the statute. If the agency did no more than identify with particularity the areas of its concern, there would be a significant gain. Doubtless there are cases in which it is difficult to do even that because of the constraints of limited time and heavy volume. The "stop" order procedure described above is designed for such cases.

The requirement that an order of suspension state the agency's reasons in writing can serve an important purpose-that of providing meaningful notice to the proponent of the tariff change and to those who would be affected by it. If that purpose is fulfilled, the power to suspend would become more than a device for providing interim protection when there is probable cause to question the validity of a proposal; it would also provide a means of eliminating some controversies and narrowing others-in either event, moving matters to a more expeditious conclusion.

\section{The Federal Communications Commission}

The common-carrier provisions of the Communications Act of 1934 follow closely the provisions of the Interstate Commerce Act outlined above. ${ }^{90}$ For present purposes, the principal difference is that the maximum period of suspension is three months, ${ }^{91}$ rather than seven. There is also a wide divergence in the volume of tariff schedules filed with the two agencies, although recent developments in telecommunication-changing technology and new services-have caused some increase in the activities of the FCC's Common Carrier Bureau. ${ }^{92}$ As

89 The failure to narrow the issues at the threshold by a meaningful statement of the reasons for suspension is compounded by the apparent reluctance of most ICC examiners to use the prehearing conference order as a clarifying device.

90 Filing requirements appear in $\$ 203$ of the Communications Act, 47 U.S.C. $\$ 203$ (1970); provision for suspension pending hearing appears in $\$ 204,47$ U.S.C. $\$ 204$ (1970); authorization of rate investigations upon the Commission's initiative or upon complaint appears in $\$ 205$, 47 U.S.C. $\$ 205$ (1970); provision for the filing of complaints appears in $\$ 208,47$ U.S.C. $\$ 208$ (1970).

9149 U.S.C. $\$ 204$ (1970).

92 The number of tariff publications filed with the FCC is far smaller. The FCC, however, does not maintain its records in a way that permits one to gather statistics as to the number of filings by any convenient method. As one would expect, some changes in schedules involve major rate changes and major new services. Most changes, however, are routine and rarely controversial. These may involve such matters as new items of station equipment in the private line services, changes in rate centers, extensions of telephone service through new mobile radio stations, and revisions in the directory of telegraph offices. Letter of FCC Chairman Dean Burch to Administrative Conference of the United States, Apr. 2, 1971, copy on file in Biddle Law Library, Univ. of Pa. Law School. 
of May 1971, thirty-five formal proceedings were being processed by the Domestic Rates Division of the Bureau. ${ }^{93}$ Of these, the largest share was initiated by complaint, and only a minor fraction by issuance of an order of suspension.

Two recent procedural steps taken by the $\mathrm{FCC}$ are worth notice. ${ }^{94}$ First, the Commission now requires that, in the case of major rate increases, the carrier submit, contemporaneous with the filing of the new schedule, the essential data on which it relies as justification for the change. In this connection, the Commission has stated that the prescribed information with respect to revenue-cost relationships is essential to a determination whether the rate is prima facie valid and should be permitted to take effect without suspension. ${ }^{95}$ Secondly, the Commission prescribed a rule extending from thirty days-as set by the statute-to sixty days, the period of time by which notice must precede a rate increase. ${ }^{96}$ This was necessary in the Commission's view "to afford the public and the Commission sufficient time to evaluate tariff filings." 97 Even though the volume of tariff filings is far lower than with the other agencies, the difficulty of gathering adequate information and appraising it within a short span of time appears to be common to all of the ratemaking agencies in the exercise of their summary powers.

The FCC experience differs materially from that of the ICC in that it has heavily relied in the ratemaking process upon a technique sometimes described-perhaps euphemistically-as "continuous surveillance." In describing this process, the chairman of the FCC observed that

it is customary for representatives of the carriers to discuss [tariff] filings with the staff of the Commission in advance of the filing in order to iron out any difficulties which may appear. These procedures operate to minimize the number

93 Despite its title, the Domestic Rates Division handles a number of cases involving matters other than rates, such as jurisdiction, interconnection of facilities, and billing practices.

94 The changes are set forth in the Final Report and Order in The Matter of Amendment of Part 61 of the Commission's Rules relating to Tariffs and Part 1 of the Commission's Rules relating to Evidence, 25 F.C.C.2d 957 (1970) [hereinafter cited as Final Report].

95 Id. 965-66.

96 The Commission finds its authorization for this change in 47 U.S.C. $\$ 203(\mathrm{~b})$ (1970), which states that "the Commission may, in its discretion and for good cause shown, modify the requirements [of notice] in particular instances or by a general order applicable to special circumstances or conditions." Id. Its order notes that the Communications Act does not contain words of limitation such as those found in the Interstate Commerce Act. Final Report, stupra note 94, 25 F.C.C.2d at 970 ; see the language of 49 U.S.C. $\$ 6(3)$ (1970) relating to "changes upon less than the notice herein specified" quoted in note 81 supra.

97 Final Report, supra note 94, 25 F.C.C.2d at $971-72$. 
of instances where suspension and formal investigation become necessary. ${ }^{98}$

The process of holding informal meetings and conferences to determine in advance by tacit agreement those changes in tariffs that should be initiated, is one which has developed in the course of the Commission's relationship with the American Telephone \& Telegraph Company. A.T. \& T. is, of course, far and away the agency's principal "client" among common carriers. The Bell system embraces twentythree Bell operating telephone companies, the Western Electric Company, which manufactures most of the equipment utilized by the operating companies, and the Bell Telephone Laboratories. ${ }^{99}$ It provides more than eighty percent of the country's telephones, and it accounts for more than ninety percent of all intercity transmission. ${ }^{\mathbf{1 0 0}}$ It also provides the lion's share of radio and television transmission facilities. Its revenue from interstate telephone tolls alone was more than $\$ 4.9$ billion for the twelve-month period ending January 31, 1971.101 A.T. \& T. has been directly and importantly involved in virtually every major common-carrier proceeding that the Commission has conducted since the passage of the Communications Act of 1934. Doubtless, it was the very magnitude and complexity of the task of regulating the Bell system that initially led the FCC to the technique of informal supervision and negotiation. By this practice comprehensive formal investigation was avoided for many years. ${ }^{102}$

On only one occasion has this procedure received more than cursory examination in the courts, in Public Utilities Commission of California v. United States. ${ }^{103}$ Reference to that opinion and record provides a fair description of the process. Believing, on the basis of reports regularly received from A.T. \& T., that the level of earnings on interstate telephone service might be excessive, the Commissioners

98 Letter of FCC Chairman Dean Burch to Administrative Conference of the United States, Apr. 2, 1971, copy on file in Biddle Law Library, Univ. of Pa. Law School.

99 A.T. \& T. owns all of the stock of most of the operating companies, a majority of the stock in 5 of them, and minority interests in 2 others. It owns all of the stock of Western Electric. A.T. \& T. and Western Electric jointly own Bell Telephone Laboratories. See AMrRican Telephone \& TelegrapH Conpany, 1970 Annual Statistical Report.

100 See American Tel. \& Tel. Co., Charges for Interstate and Foreign Communication Service, 9 F.C.C.2d 30, 38-39 (1967).

101 The source of this datum is A.T. \& T.'s administrative reports to the Domestic Rates Division of the FCC.

102 The practice of conducting informal meetings between communications carriers and the Commission to discuss interstate rates is noted in 3 FCC ANN. REP. 91 (1937) and in 6 FCC ANN. REP. 30 (1940).

103 Public Util. Comm'n of Cal. v. United States, 356 F.2d 236 (9th Cir.), cert. denied, 385 U.S. 816 (1966). 
and staff members of the Common Carrier Bureau met informally with representatives of the Bell system on six different days during July, September, and October of 1964. The Commissioners listened to presentations by Bell officials, Commission staff members, and several outside consultants. The presentation took the form of unsworn testimony, and various supporting charts and exhibits were submitted. The participants also made opening and closing arguments. A transcript of the proceedings was maintained. ${ }^{104}$ Thereafter, the Commission met further with Bell officials to discuss questions raised by the various presentations. In November 1964, the Commission issued a public notice "stating that the Bell System companies would submit tariffs proposing major reductions in interstate telephone rates amounting to approximately 100 million dollars annually." 105 The notice declared that the reduction was "made possible by the high level of business activity and increasing efficiencies in telephone operations." 106 The notice did not purport to make findings concerning the appropriate rate of return to be allowed Bell on its interstate operations; nor did it expressly state that the proposed rates would be just and reasonable.

Thereafter, the California Public Utilities Commission, on behalf of the ratepayers of that state, requested a rehearing in the matter of the meetings that had been held, to consider the interstate earnings of the Bell System, arguing that the closed proceedings had denied it the opportunity to be heard and that the Commission had failed in various ways to discharge its ratemaking responsibilities. ${ }^{107}$ The FCC "dismissed the petition for rehearing on the principal ground that 'The Public Notice . . . did not and could not bind anyone to any action, nor was it a ruling on the proposed tariff filing." "108 The State Commission then turned to the court of appeals, urging it to remand the

$104 I d$. at 238. It is evident from this description that by 1964 the informal meetings with A.T. \& T. had become somewhat formalized. In the early years, the meetings were more on the order of ordinary round-table bargaining sessions.

$105 I d$.

106 Joint Appendix filed with Court of Appeals at 2-3, Public Util. Comm'n of Cal. v. United States, 356 F.2d 236 (9th Cir. 1966). that:

107 The California Commission subsequently contended before the court of appeals

FCC has approved or prescribed such rates supposedly to yield a reasonable return without finding what the return is or should be, or on what property it is earned, or the operating expenses attributable to interstate toll, or whether such expenses are reasonable, or whether the rates it has prescribed or approved are reasonable.

Opening Brief for Petitioner at 15, Public Util. Comm'n of Cal. v. United States, 356 F.2d 236 (9th Cir. 1966).

108356 F.2d at 238. The FCC also stated that the State would be free to file a complaint challenging the reasonableness of the proposed rates when they were filed. $I d$. at 240 . To this the California Commission replied that the vital proceeding had already been held and the FCC was seeking to shift to the appellant investigative responsibilities that the agency alone was equipped to fulfill. See id. at $240-41$. 
proceedings with directions to the $\mathrm{FCC}$ to issue notice, to hold public hearings with full opportunity to interested parties to be heard, to make findings in accordance with the ratemaking provisions of the Act, and to enter an order prescribing just and reasonable rates. In the court's view, the case "boil[ed] down to the question whether the rates announced in the Commission's Public Notice were carrier-made or Commission-made . . . ." 109 The court's answer was that the Commission's actions fell short of approval or prescription of the proposed rates, and that the appellant's only remedy would be to lodge a complaint with the federal agency if those rates were filed and if the FCC did not choose to initiate a formal investigation of them. ${ }^{110}$

One may examine the technique of informal negotiation described above by posing several somewhat related questions. What are its practical advantages and disadvantages compared to a procedure that is open and adversary? Is it consistent with the design of the regulatory scheme enacted by Congress? Did the Court of Appeals for the Ninth Circuit correctly rule in Public Utilities Commission of California that the matter was beyond its reach? Perhaps consideration of the last of these questions is best postponed until the discussion of the ratemaking procedures of the Civil Aeronautics Board. ${ }^{111}$ Those procedures were subjected to judicial scrutiny in Moss v. $C A B,{ }^{112}$ and the opinion in that case, if it is not irreconcilable with the Ninth Circuit's holding, certainly reflects a sharply different judicial attitude.

Since the FCC consistently employed its informal approach to the Bell system until 1965, one naturally turns to that prolonged experience in seeking to arrive at a practical judgment, although it should be acknowledged at the outset that the verdict of those who have observed the FCC's performance is a divided one. The obvious virtue of a bargaining process is that it offers the prospect of a more expeditious solution than the conduct of a formal case. Members of the Commission have long defended it on this ground. Former FCC Chairman Rosel $\mathrm{H}$. Hyde echoed this view in describing the development of this procedure at a congressional hearing:

One of the first projects of the newly created Federal Communications Commission in 1934 was an investigation of the telephone industry, which was a very broad investigation in respect to all of its operations.

But, before it was concluded, the Commission resorted to negotiations in order to make immediately available the 
changes in rates and regulations which the investigation indicated might be appropriate. And, as a result of that investigation, the Commission adopted a policy, not an exclusive policy, but a pretty general policy of trying to maintain a system of continuous regulation that would keep abreast of changes from year to year rather than have the Commission resort to tremendous hearings which could last several years and which could delay-or which could end up at a time when the conditions which prompted the investigation might not be current. ${ }^{113}$

It has also been argued that, as a consequence of arrangements that it has made for the reporting of information and data, the FCC "has at its disposal at all times a veritable fluoroscope of Bell telephone system operating performance." 114 The author of this claim, the editor of Public Utilities Fortnightly, has also stated that "judging by results accomplished" the FCC's "continuous surveillance" has been a marked success. ${ }^{115}$ Writing in 1963, he observed that during the period of regulation some fifty changes in rates had been negotiated with Bell; that most of these involved reductions; that "[i] nterstate long-distance telephone rates today [1963] are nineteen per cent lower than they were in 1940, even though prices generally have more than doubled;" and that "[1] ong haul calls have benefited even more from rate reductions." 116 Others, including a number of congressmen, have been more skeptical of the benefits produced by the FCC's bargaining process. ${ }^{117}$

The agreement of the Bell system to numerous reductions during the period between 1940 and the mid-sixties in-and-of-itself proves little. Technological developments had opened the way to some spectacular cost savings. One Commissioner observed in 1967 that the then current cost of transmitting a telephone message by high-capacity microwave relay towers was "about 1 percent of the cost of moving it

113 Hearings on Antitrust Problens of the Space Satellite Conmunications System Before the Subcomm. on Antitrust \& Monopoly of the Senate Comm. on the Judiciary, 87th Cong., 2d Sess., pt. 2, at 290-91 (1962).

114 Welch, Constant Surveillance: A Modern Regulatory Tool, 8 VIn. L. Rev. 340,352 (1963).

115 Id. 359.

116 Id.

117 See Hearings on Antitrust Problems of the Space Satellite Communications System Before the Subcomm. on Antitrust \& Monopoly of the Senate Comm. on the Judiciary, 87th Cong., 2d Sess., pt. 2, at 282-83, 292-93, 698-757 (1962) ; Hearings on S. 2814 (Communications Satellite Legislation) Before the Senate Comm. on Commerce, 87th Cong., 2d Sess. 79-96 (1962) ; Hearings on a Progress Report of Federal Communications Commission Before the Subcomm. on Communications of the Sente Comm. on Commerce, 88th Cong., 1st Sess., ser. 8 (1963). 
by conventional telephone line 30 years ago." 118 Moreover, the telephone industry is one of markedly declining costs, and long-distance circuits were operating far below the level of saturation throughout the period in question. Reductions in rates tapped the elastic demand for long-distance service, stimulating the volume of business to a degree that produced constant improvement in earnings. ${ }^{119}$ There is thus reason to believe that A.T. \& T., behaving as a rational monopolist unregulated by federal authority, would have made reductions no less substantial than those to which it acquiesced in its conferences with the FCC.

118 American Tel. \& Tel. Co., Charges for Interstate and Foreign Communication Service, 9 F.C.C.2d 30, 133 (1967) (Comm'r Johnson concurring).

119 The FCC initiated a comprehensive formal investigation of A.T. \& $T$. in 1965. Its 1967 decision disposing of the first phase of that investigation found in part that:

324. The Commission's staff submitted for the record certain operating reports supplied by A.T. \& T. which contain interstate earnings ratios and other selected operating statistics for the years 1955 through 1966. A staff witness also presented testimony and exhibits with respect to trends in selected interstate operations for the period since 1955.

325. The record clearly shows that there has been a consistent and substantial growth in interstate messages, revenues, and average revenue per message over the past decade. It also shows that this growth has more than offset the depressing effect on earnings of increases in investment and expenses, including wage increases. During the past 10 years the interstate earnings ratio has increased more than one percentage point (from 6.9 percent for 1957 to 8.2 percent for 1966 on the company's basis of computation) notwithstanding three major reductions in interstate message toll telephone rates (in 1959, 1963, and 1965) and two major revisions in separations procedures (in 1962 and 1965) which increased interstate revenue requirements. During this period, the average annual increase in messages was 8.4 percent and revenues from all interstate services increased at an average rate of 10.6 percent per year. This rate of growth in revenues, coupled with a lower average increase in expenses and taxes of 9.9 percent, resulted in an average annual increase in net earnings, as reported by A.T. \& T., of 13.9 percent. Since the average annual increase in net investment was only 12 percent during this period, the resulting earnings ratios improved substantially over this span of years. None of the foregoing growth figures are adjusted to reflect the effect of the aforementioned rate reductions and revisions in the separations procedures and, therefore, do not reveal the full extent of the upward trend in interstate earnings. If such adjustments were made, the indicated growth in earnings would be substantially higher.

326. Another factor in the growth trends is the stimulating effect on the volume of business resulting from the interstate message toll telephone rate reductions during this period. The record shows that there was an acceleration in the rate of growth in messages starting in 1964. This acceleration in the rate of growth in messages was coincident with the substantial reductions in interstate message rates in 1963, when the "after 9" rates were introduced, and in 1965, when the $\$ 100$ million reduction in rates became effective. Since the evidence introduced in this phase of the proceedings does not include an analysis of the stimulating effect of these rate reductions, we will not attempt to assess, in this interim decision, the effects of such rate reductions on message volume and interstate earnings. However, on the basis of the record, we are of the opinion that the long-term trend of improving interstate earnings will continue for the foreseeable future, subject, of course, to short-term variations.

Id. at 112-13. 
The suggestion that the Commission's staff has been in a position to observe every heartbeat of the Bell system is ludicrous. The resources of the Common Carrier Bureau have ordinarily permitted it to devote annually approximately five or six man-years to examination of Bell's activities. To this date the Bureau lacks an adequate staff of economists. ${ }^{120}$ Over the years it has had relatively few lawyers skilled in the regulation of public utilities. The paucity of its resources has made the Bureau extremely dependent upon A.T. \& T., a company equipped with an impressive array of professional and technical talent. ${ }^{121}$ It is true that the company submits a large body of information and data to the agency. The significance of the submissions, however, turns in large part upon the validity of the underlying premises and assumptions. For example, the "facts" that ostensibly reflect the cost of providing interstate telephone service depend, among other things, upon the method of allocating a variety of joint costs between interstate and local service. Different methods will produce widely divergent results. ${ }^{122}$ The theoretical and practical problems involved in allocating costs between different types and classes of service for purposes of

120 When the Commission has instituted formal proceedings, it has been obliged to rely heavily upon outside consultants retained for the occasion.

I21 At the conclusion of the first phase of the FCC's formal proceeding involving the A.T. \& T. system, Commissioner Johnson spoke to the problem of regulating the Bell system:

The FCC's Common Carrier Bureau (which carries prime responsibility for the Commission's telephone regulation) is staffed with able and dedicated men. But there are only 100 professionals in the Bureau, and they must also bear the burden of overseeing Western Union, numerous other communications common carriers, all American-based international communications companies, and administration of the Communications Satellite Act. The contrast between the Bureau's task and its resources speaks for itself.

Indeed, lack of resources is an even more serious problem for State and municipal regulatory bodies. And the splintering of jurisdiction between the Federal Government and the States undoubtedly contributes further to the deterioration of effective, coordinated regulation. A.T. \& T. is so much bigger, and better financed, than any government agency it confronts that even the process of selecting which information it will offer the regulator gives the whole operation a substantial aura of self-evaluation.

9 F.C.C.2d at 137 (concurring opinion).

122 An illustration is provided by the Commission's disposition of one aspect of the "separations" question (allocating equipment values between Federal and State jurisdictions) considered in its 1967 A.T. \& T. decision. One of the numerous elements in an exchange plant is known as "subscriber plant"-telephone instruments and lines to the local office. An allocation based solely upon use would have put $4 \%$ of the value of subscriber plant in the interstate rate base. That is to say, during the period of actual use, the average telephone is utilized $4 \%$ of the time for interstate long-distance calls. Bell, however, for various reasons, proposed a formula that would have allocated $15.6 \%$ of this item to the interstate base. The Commission determined that the allocation should be $12 \%$. The difference between the 2 rates increased the interstate rate base by $\$ 85,000,000$. See $i d$. at 128-29.

On October 27, 1970, the Commission concluded a subsequent proceeding that had reopened the whole question of jurisdictional separations. Separation Procedures, 26 F.C.C.2d 248 (1970). Its decision adopted a new formulation, shifting approximately $\$ 130,000,000$ from the intrastate, to the interstate, telephone ratemaking base. Id. at 260 (Comm'r Johnson dissenting). 
designing rates are no less severe. Commissioner Nicholas Johnson has correctly observed that the process by which the Bell system has provided information to the Commission has "a substantial aura of self-evaluation." 123

Subsequent developments must be considered in appraising the accomplishments of the fifty-odd rate negotiations conducted by the FCC with Bell prior to 1963. In 1963, the FCC completed what might be considered its first formal rate investigation of major proportions, a proceeding designed to determine the lawfulness of the tariff schedules of A.T. \& T. and the Western Union Telegraph Company, covering so-called "private line" telephone and telegraph services. ${ }^{124}$ The Commission concluded, following extended hearings in which the users vigorously participated, that A.T. \& T. had substantially underpriced services that were competitive with Western Union and was charging excessive rates for the noncompetitive services. It decided to prescribe a drastically altered rate design that would produce reasonable earnings at approximately the same level for all of A.T. \& T.'s private line services. ${ }^{125}$

Not until 1965 did the Commission initiate a comprehensive investigation of A.T. \& T. ${ }^{126}$ Again, it noted a wide variation in earnings among various services. Among the issues designated for consideration were separations procedures, i.e., allocation of joint costs; operating costs, including particularly the reasonableness of prices paid by Bell operating companies to Western Electric for equipment, supplies, and service; fair rate of return; and the design of rates for the various types of services offered to Bell's customers. The then Chairman, Commissioner Henry, noted that "the widely divergent rates of return earned by the various services" of A.T. \& T. raised serious questions that required full exploration; that disagreements as to a separation formula had been persistent but had generally been settled "so to speak, out of court;" and that questions involving the earnings and prices of Western Electric "remain largely unexplored in depth." There was need, he concluded, for a "broad-gauged" public hearing that would expose the

1239 F.C.C.2d at 137.

124 A.T. \& $T$. and Western Union Private Line Cases, 34 F.C.C. 217 (1963). Private line services are valuable to users having specialized or bulk communication requirements on a scale that makes it economical to lease facilities. Established users include the General Services Administration, stock exchanges, and the press. Private line services accounted for about $2 \%$ of A.T. \& T. revenues at the time of the proceeding.

$125 I d$. at 301 .

126 American Tel. \& Tel. Co., 2 F.C.C.2d 871 (1965). In denying reconsideration of the order directing a formal investigation, the Commission stated pointedly that it was not repudiating continuous surveillance and intended to use the method again "under appropriate circumstances." American Tel. \& Tel. Co., 6 P \& F Radio Reg. 2D $662,666-67$ (1965). 
entire subject of the FCC's relationship with the Bell system to "the critical, searching spotlight of public scrutiny." ${ }^{127}$

A phase of the comprehensive investigation was concluded in 1967, at which point the Commission modified its separation formula ${ }^{128}$ and decided that the rates of the operating companies should be reduced to produce a substantially lower rate of return (in the range of seven to seven and one-half percent) on the interstate rate base. ${ }^{129}$ Issues of rate design were left open. ${ }^{130}$ The question of the accuracy of A.T. \& T.'s costs as reflected by the prices paid to Western Electricits major supplier of equipment-remains untouched to the present day. ${ }^{131}$

For many years the FCC used the threat of invocation of its formal powers as a means of avoiding their actual employment. A.T. \& T., for its part, has been more than willing to substitute negotiation for adversary proceedings. When the FCC initiated a comprehensive formal proceeding in 1965, the company protested that the Commission ought not abandon the tried and true, and the agency replied that it was not permanently discarding the informal approach. ${ }^{132}$ If "continuous surveillance" has been successful in the sense that negotiations characteristically have resulted in prompt agreement, it has also had serious defects and limitations. Informal settlement-the easy wayhas had its costs, and, if those costs were once somewhat hidden, over the course of time they have become increasingly evident. The regulatory agency has conspicuously failed to overcome its considerable dependence upon the regulated company. It has failed to develop a staff with some semblance of the size, skill, and strength requisite for its formidable task of understanding and coping with the myriad and complex problems of regulating the country's largest and most impor-

127 American Tel. \& Tel. Co., 6 P \& F Radio Reg. 2D 662, 668-69 (1965) (concurring statement of Chairman Henry).

128 American Tel. \& Tel. Co., Charges for Interstate and Foreign Communication Service, 9 F.C.C.2d 30 (1967).

129 In November 1970, A.T. \& T. filed proposed tariff changes calling for increases in long-distance telephone rates. The increases are predicated in part upon a claim that the company should be allowed a $9.5 \%$ rate of return. They were suspended by a Commission order dated January 21, 1971. 27 F.C.C.2d 149 (1971).

130 Proceedings involving the design of rates are pending, and the Commission has called for expedition. Id. at 161 .

131 Id. at 169-170 (Comm'r Johnson concurring). The prolonged failure of the Commission to confront issues relating to Western Electric is also discussed in Note, The Federal Communications Commission and the Bell System: Abdication of Regulatory Responsibility, 44 IND. L.J. 459 (1969). The magnitude of the issue is suggested by the fact that Western Electric's sales to Bell operating companies amounted to more than $\$ 4.9$ billion in 1970. 1970 Western Electric ANN. REP. 13.

132 American Tel. \& Tel. Co., 6 P \& F Radro Reg. 2D 662, 666-67 (1965). 
tant monopolistic enterprise. Obtaining what it regarded as concessions from the company, the agency continued to postpone from year to year and decade to decade confrontation with the hard questions. ${ }^{133}$ At its best, the regulatory process develops visible and coherent principles of decision, particularized criteria and standards, and a competent methodology.$^{134}$ Only when this has taken place do proceedings go forward within predictable channels; only then do they become more manageable and less protracted. The FCC's technique of invisible decisionmaking by informal bargaining has long delayed such a development. As a result, regulation proceeds even now at a pace of gasp and halt.

It also appears inconsistent with the scheme of the regulatory statutes under consideration to carry informal procedures to the lengths that they have been taken by the FCC in the practice of "continuous surveillance." There is no doubt of the propriety, indeed the desirability, of opening and maintaining free channels of communication between the agency and the regulated company. Informal procedures will often be better adapted to securing information, identifying problems, and exploring matters of present or potential concern. It would seem quite appropriate for a commission staff to make preliminary investigations, by whatever informal means are convenient, to ascertain whether a regulated company is obtaining disparate earnings from its various classes of service. It would likewise be eminently reasonable, if inequities in the rate design became apparent, to request the company to initiate remedial changes. It is quite another matter, however, for the Commissioners to meet with company officials to negotiate rates that the company would be prepared to propose and

${ }^{133}$ As indicated above, the Commission has yet to resolve some questions, relating to the Bell System, that are basic in the process of conventional ratemaking. Not surprisingly, it has also failed to address itself to less conventional questionsquestions relating to such matters as efficiency, innovation, and quality of service.

134 The point that informal bargaining does not lead to such a development does not imply that principles and standards can only emerge through the conduct of adjudicatory-type hearings. In some instances, rulemaking may be an effective complement. See FPC v. Texaco Inc., 377 U.S. 33 (1964) ; American Airlines, Inc. v. CAB, 359 F.2d 624 (D.C. Cir.), cert. denied, 385 U.S. 843 (1966). The functions of adjudication and rulemaking "merge at many points," NLRB v. Wyman-Gordon Co., 394 U.S. 759, 770 (1969) (Black, J., concurring), and one commentator has recently and persuasively urged that the agencies, within the limits of their discretion, should "fashion hybrid or conglomerate procedural devices which would utilize those characteristics of both adjudication and rulemaking that are most appropriate in light of the circumstances and issues of the particular case." Clagett, Informal Action-Adjudication-Rule Making: Some Recent Developments in Federal Administrative Laze, 1971 DuKE L.J. 51, 70.

For its current investigation of domestic passenger fares, instituted by Order 70-1-147, Jan. 30, 1970, the CAB has divided the complex and massive proceeding into 10 phases. It has conducted certain phases, for example, the treatment of flight equipment depreciation, leased aircraft, and deferred federal income taxes, by notice of rulemaking. Other phases such as passenger load-factor standards applicable to fare determinations and the level and structure of passenger fares have been the subject of extended evidentiary hearings. 
the Commission prepared to accept. ${ }^{135}$ It is fundamental in the various federal ratemaking schemes that rates are to be established initially by the carrier or utility and that the Commission, acting in the exercise of an independent judgment, is then to employ its powers of visitation, review, and correction. ${ }^{136}$ The regulatory agency cannot simultaneously function effectively as an independent reviewing authority and as a participant in the negotiation of the proposal under examination. If an agency uses the weight of its reserved powers in a bargaining process with a carrier, other persons who may be affected by the result are effectively excluded, even though the regulatory statutes contemplate that they will be afforded an opportunity to be heard in instances in which governmental authority is being brought to bear. ${ }^{137}$ It is true that aggrieved persons may file a complaint when the regulatory commission refrains from exercising its powers of suspension and investigation. In such instances, however, they will bear the burden of proof and must be prepared to "go it alone." ${ }^{38}$ This is a particularly uninviting prospect when it appears that the agency has in effect prejudged the matter.

\section{Conclusions}

"Continuous surveillance," as practiced by the FCC, is a misnomer. The Commission has had little mastery of the subject matter it purports to scrutinize. Its technique of proceeding by informal consultation, doubtless prompted at the outset by the formidable dimensions of its task, has tended to perpetuate the agency's dependence upon the Bell System's technical and professional experts. As a result, the Commission has been slow to build an adequate staff, develop an independent expertise, and articulate the basis of its decisionmaking. The slow pace at which it has proceeded with its first comprehensive investigation of A.T. \& T., initiated in 1965, largely reflects these deficiencies rather than any inherent defects in formal administrative processes.

In the long run, regulation by a system of decisionmaking that fails to explain itself is bound to engender public distrust. That this

135 It is doubtless true that when the FCC and A.T. \& T. sit down in advance of a filing to "iron out any difficulties" neither becomes technically bound by the understanding reached. Nonetheless, the understanding reflects the agency's informal determination, to which the agency is, as a practical matter, committed.

136 See United Gas Pipe Line Co. v. Mobile Gas Serv. Corp., 350 U.S. 332, $339-43$ (1956) ; Arizona Grocery Co. v. Atchison T. \& S.F. Ry., 284 U.S. 370, 383-87 (1932).

137 Thus, the Communications Act provides that when the Commission suspends a new rate it shall conduct a "full hearing." 47 U.S.C. $\$ 204$ (1970). So too, when it conducts a rate investigation on its own initiative, the Commission shall afford "full opportunity for hearing." Id. \$205.

138 See text accompanying notes 108-10 supra. 
did not occur on a more serious scale in the case of the FCC's commoncarrier regulation is attributable to the failure, until 1970, of A.T. \& T. to seek overall increases in its charges. But, the halcyon days that enabled the FCC to announce from time to time, with fanfare, that Bell was about to reduce long-distance telephone charges are past. The proposed tariff changes filed by A.T. \& T. on November 20,1970, were designed to produce the biggest dollar increase in earnings ever sought by a regulated company. ${ }^{139}$

To question the FCC's approach is not to argue for an artificial separation of those who represent the agency from those who speak for the company. Exploration by informal exchange of information and views is a practical necessity. To be sure, it is not always easy to mark the precise place at which exploration leaves off and disposition begins. $^{140}$ If, however, the Commission were to accept the thesis that has been presented here-that its form of "continuous surveillance" is in effect decisionmaking and should be abandoned both because it is ungoverned by discernible principle and inconsistent with the statutory scheme-it would face no exceptional problem in avoiding the appearance, as well as the reality, of invisible decisionmaking. The first and

139 Assuming no change in the volumes and composition of messages projected for 1971, the proposals would have resulted in increased revenues of approximately $\$ 760$ million annually. The company estimated, however, that the increased revenues would amount to $\$ 385$ million because of shrinkage (reduced volumes because of higher rates), shifts (the shifting of calls to a time period when lower rates prevail), and reclassifications (use of a class of service, e.g., customer-dialed in lieu of operatorhandled calls, carrying lower rates). The schedules were designed to encourage customers to use the network during off-peak periods and to place calls without operator assistance when feasible. It was further estimated that the rate revisions would reduce costs by about $\$ 160$ million in 1971 . On these assumptions, the increase in earnings before taxes would be approximately $\$ 545$ million. American Tel. \& Tel. Co., 27 F.C.C.2d 151, 152 (1971).

The Commission's response to this filing provides an illustration of the use of informal processes in a manner quite consistent with the performance of the agency's responsibilities. By letter of January 12, 1971, the FCC requested the company to postpone voluntarily the effective date of the tariffs filed pending the outcome of an expedited hearing. It also granted special permission to the company to file for interim increases that would produce not more than $\$ 250$ million. The Commission indicated that the interim increases would be permitted to take effect after a brief period of suspension, but would be subject to an accounting order with provision for refund. The company complied with the request, and the Commission suspended the revised increases for a 1-week period. The net result was that the company was authorized to collect without significant delay a portion of the total increases sought. The customers' interests are protected by the accounting order that accompanied the suspension. While the Commission has made an interlocutory determination that the balance of convenience favors allowing a portion of the proposed increases to take effect without imposing the maximum period of suspension, it has made no commitment as to the extent of the increase that it may ultimately find justified. $I d$, at 154 .

140 See Phillips v. SEC, 153 F.2d 27 (2d Cir.), cert. denied, 328 U.S. 860 (1946), in which the court concluded that conversations between SEC personnel and the president of a company involved in a proceeding under the Public Utility Holding Company Act of 1935 , $\S 11(\mathrm{e}), 15$ U.S.C. $\$ 79 k(\mathrm{e})$ (1970), were not shown to have prejudiced the cause because "the Commission ... did not hold itself bound by any of the preliminary steps, but gave the final judgment upon its view of the law and in the exercise of a discretion which appears rational and reasonable." 153 F.2d at 32 . 
principal step would be to cease scheduling private en banc conferences with the industry's bargaining representatives and to delegate to staff the performance of the essential groundwork involved in the ratemaking process.

\section{The Ctvil Aeronautics Board}

As in the case of communications, the statutory provisions for the economic regulation of the air carrier industry in the Federal Aviation Act ${ }^{141}$ are patterned on the Interstate Commerce Act. Several differences should, however, be briefly noted. The maximum period of suspension is 180 days beyond the date when a tariff change would otherwise go into effect. The Board lacks power to provide for refunds in the situation in which a rate is put into effect following expiration of the suspension period but prior to completion of the administrative proceeding. ${ }^{142}$ In handling complaints, the Board appears to have a somewhat broader discretion than the agencies previously discussed. ${ }^{143}$

Although the Board does not collect statistics on the number of rate filings submitted, it is evident that the volume is but a small fraction of that received by the ICC. ${ }^{144}$ Some basis for comparison is provided

141 Provisions of the Civil Aeronautics Act of 1938 were re-enacted in the Federal Aviation Act of 1958. Filing requirements are set forth in $\$ 403,49$ U.S.C. $\$ 1373$ (1970). Provisions for suspension, investigation, and complaint appear in $\S 1002,49$ U.S.C. $\$ 1482(1970)$.

142 In this respect it is unlike Part I of the Interstate Commerce Act, 47 U.S.C. $\$ 204$ (1970) (rail carriers), and the Communications Act, 49 U.S.C. $\$ 15(7)$ (1970), but similar to Part II of the Interstate Commerce Act (motor carriers), 49 U.S.C.' $\$ 316(\mathrm{~g})(1970)$. The Federal Aviation Act also corresponds to the motor carrier portions of the Interstate Commerce Act, in that it omits any provision authorizing the agency to award reparations for past excessive charges. See T.I.M.E., Inc. v. United States, 359 U.S. 464, 478-80 (1959).

143 Compare $\$ 13(1)$ of the Interstate Commerce Act, 49 U.S.C. $\$ 13(1)$ (1970), and $\S 208$ of the Communications Act, 47 U.S.C. $\$ 208$ (1970), with $\S 1002$ (a) of the Federal Aviation Act, 49 U.S.C. \$1482(a) (1970). Under all 3 provisions "any person" may file a complaint charging violation of the relevant statute. Each additionally provides in substance that, if the complaint is unsatisfied by the carrier, it shall be the duty of the agency to investigate if there appears to be any "reasonable ground" for doing so. Section 1002 (a), however, unlike the other sections cited, goes on to provide that whenever "the Board is of the opinion that any complaint does not state facts which warrant an investigation or action, such complaint may be dismissed without hearing." 49 U.S.C. \$1482(a) (1970). The courts have given some weight to this additional language, although they have also made it clear that, at least in some circumstances, the discretion conferred is less than absolute. See Trailways of New England v. CAB, 412 F.2d 926 (1st Cir. 1969) ; Transcontinental Bus Sys., Inc. v. CAB, 383 F.2d 466 (5th Cir. 1967), cert. denied, 390 U.S. 920 (1968); Nebraska Dep't of Aeronautics v. CAB, 298 F.2d 286 (8th Cir. 1962). See also Flying Tiger Line, Inc. v. CAB, 350 F.2d 462 (D.C. Cir. 1965), cert. denied, 385 U.S. 945 (1966).

144 Data and estimates appearing in this paragraph were obtained from the Board in response to inquiries by the author and are confirmed by letters received from Whitney Gillilland, Vice Chairman (Apr. 20, 1971), and Alfred R. Stout, Chief, Passenger and Cargo Rates Division, Bureau of Economics (June 25, 1971), copies on file in Biddle Law Library, Univ, of Pa. Law School. 
by the Board's issuance in 1969 and 1970 of a total of 104 suspension orders, ${ }^{145}$ compared to the issuance of more than 3300 by the ICC during the same period. ${ }^{\mathbf{1 4 6}}$ The Board estimates that fewer than five percent of those filings subject to suspension are in fact suspended. ${ }^{\mathbf{1 4 7}}$ During 1969 and 1970 approximately ninety percent of those tariffs that were suspended were later withdrawn by the filing carrier. This figure appears to be fairly representative of earlier periods as well. Thus, only a very small proportion of those tariffs subjected to a suspension order become the subject of a formal investigation. At the end of May 1971 the Board carried fifty-three formal rate investigations on its docket. Twenty-two of these were at or beyond the stage of the pre-hearing conference. Past experience indicates that it is likely that a high proportion of the remaining thirty-one, those not yet set for pre-hearing conference, will be withdrawn by the carrier. Although it is not uncommon for competing carriers and users of air transportation to request formal investigation of rate filings, their complaints are frequently dismissed without a hearing. ${ }^{148}$

Just as the FCC over the years has exhibited a reluctance to face the complex economic issues involved in regulation of A.T. \& T., the $\mathrm{CAB}$ long avoided a full confrontation with the issues involved in the regulation of the domestic passenger fares charged by the airlines. ${ }^{149}$ A general investigation of the level of passenger fares, instituted in 1956, was terminated in $1960,{ }^{150}$ when the Board concluded that the record before it was inadequate to provide a basis for fixing just and reasonable rates. ${ }^{151}$ In that investigation the Board did attempt to elaborate certain standards to "be used in assessing future fare proposals of the carriers . . . ."152 Even on this level, however, the results proved less than fruitful. The standards were too vague to

145 Some of these orders involved more than 1 filing. A large proportion of the filings received by the Board and of the suspension orders issued involve air freight as distinguished from air passenger service.

146 Appendix B.

147 Rates applicable to foreign air transportation are not subject to suspension.

148 On occasion the Board has been challenged in the exercise of its discretion to dismiss without hearing. See cases cited note 143 supra.

149 The Board has conducted numerous formal proceedings involving rates for various categories of air freight. It has also had occasion to deal recurrently with promotional fares of various descriptions, such as night coach service, family fares, youth fares, and fares for military personnel.

150 General Passenger-Fare Investigation, 32 C.A.B. 291 (1960).

$151 \mathrm{Id}$. at 328. The Board's failure to prescribe rates elicited an unsuccessful challenge from Eastern Air Lines. Eastern Air Lines, Inc. v. CAB, 294 F.2d 235 (D.C. Cir.), cert. denied, 368 U.S. 927 (1961). For a complete discussion of the origins and course of the administrative proceeding, see Redford, The General Passenger Fare Investigation, in GovernMENT REGULATION OF BuSINESS 336 (E. Bock ed. 1965).

152 General Passenger-Fare Investigation, 32 C.A.B. 291, 294 (1960). 
serve as an effective guide, and the opinion left some of the critical questions untouched. An extensive investigation instituted in 1970 is now in progress ${ }^{153}$ and, considering its scope and complexity, is proceeding at a comparatively rapid pace. ${ }^{154}$

The feature of Board proceedings that significantly differentiates its approach to ratemaking from that of other agencies is its frequent use of what it terms the "speaking" suspension order-an order that tells the carrier, with more or less specificity, what kind of substitute proposal will be deemed acceptable. During the five years preceding the 1970 decision in Moss $v$. CAB, ${ }^{155}$ almost half of the Board's suspension orders contained such advice. ${ }^{156}$ As carriers ordinarily wish to avoid administrative delay, engagement in formal proceedings, and the pursuit of unpromising causes, they have responded to speaking orders in most instances by withdrawing the suspended tariff and filing a substitute. ${ }^{157}$ Although the Board has issued no speaking orders since July 1970, when Moss found an order of that species invalid, it regards the device as a highly effective administrative tool.

To appraise the ramifications of the Moss decision one must first examine its background. ${ }^{158}$ On August 1, 1969, United Air Lines filed for an increase in passenger fares (the second within six months) marked to become effective on September 15, 1969. New tariffs were filed shortly thereafter by several other trunkline carriers, with proposed effective dates in late September and early October. During the

153 The long hiatus following the inconclusive opinion of 1960 is probably attributable in part to fairly stable rates throughout most of the ensuing decade.

154 See note 134 supra.

155430 F.2d 891 (D.C. Cir. 1970).

156 Letter from Vice Chairman Gillilland to Ralph S. Spritzer, Apr. 20, 1971, copy on file in Biddle Law Library, Univ. of Pa. Law School. The Chairman added:

This advice depended, of course, upon the facts and circumstances of a particular filing and whether the Board believed it had sufficient information available to it at that point in the proceeding.

Id. The Board's regulations, 14 C.F.R. $\$ 221.165$ (1971), require the submission of detailed data and information when the carrier files a tariff publication containing new or changed rates or new or changed classifications, rules, regulations, or practices affecting rates. Board personnel have stated to the author, however, that compliance with this requirement has been erratic.

157 See R. Caves, Am Transport and Its Regulators 362 (1962); cf. E. Redford, The Regulatory Process 148-49 (1969).

An indication of the industry's concern over delays in effectuating rate changes is found in the Air Transport Association's recent proposal that the Board be denied power to suspend fare increases in circumstances in which the carrier's rate of return is less than $10.5 \%$. Washington Post, Jan. 6, 1971, $\S \mathrm{D}$, at 8. Assistant Secretary Charles D. Baker, speaking for the Department of Transportation, has suggested that airlines should be permitted to adjust rates within a predetermined "zone of reasonableness" without being subject to the initiation of Board proceedings. Philadelphia Inquirer, Feb. 12, 1971, at 52.

158 Facts not noted in the court of appeals' opinion are based on the record filed with that court, and on C.A.B. Order of Investigation and Suspension, No. 69-9-68, Docket 21,322 (Sept. 12, 1969). 
preceding months, the Board had met several times with the carriers to discuss their economic situation. Another meeting was scheduled for August 14. Congressman John E. Moss, a member of the House Committee on Government Operations who had previously protested the conduct of ex parte meetings, requested that, if the scheduled meeting were held, he be permitted to attend. The Board's Chairman responded by letter in which he refused to allow the Congressman to attend, stating that the meeting would be a continuation of a prior conference and would "discuss matters of the domestic fare structure and fare formulas rather than fare level." ${ }^{159} \mathrm{He}$ added that a transcript would be prepared.

On August 19, the Board called for argument on the question whether it should suspend the proposed tariffs, permit them to take effect while conducting an investigation, or permit them to take effect without investigation. Congressman Moss and his congressional col leagues, however, refused to participate in this proceeding because they believed that in practical effect the Board had already made its decision on the proposed tariffs.

Following oral argument, Congressman Moss wrote to the Board's Chairman urging that the Board confine itself to its statutory functions. He declared that "ratemaking by treaty must come to an end," and that it is "not the duty of the Board to propose alternative fare proposals when the person proposing . . . changes cannot show that its proposed change is just and reasonable." 180 Chairman Crooker's response indicated that if the Board decided to suspend, it would indeed make known its position "as to other kinds of tariff proposals it would approve." 101

On September 12, the Board issued an order suspending the effectiveness of the proposed tariffs on the ground that they "may be . . . unlawful and should be suspended pending investigation." The Board proceeded to state its "opinion that the carriers have adequately demonstrated a need for some additional revenue" and that it "would be disposed to grant an increase computed in accordance with the criteria set out below." ${ }^{162}$ The Board then set forth a comprehensive formula, sufficiently detailed to provide a basis for computing with precision all of the carrier's fares. ${ }^{163}$ It contained, among others, the

159 Brief for Petitioners at 5, Moss v. CAB, 430 F.2d 891 (D.C. Cir. 1970).

$160 \mathrm{Id} .10$.

161 Id.

162 C.A.B. Order of Investigation and Suspension, No. 69-9-68, Docket 21,322 (Sept. 12, 1969).

163 The formula corresponded closely to the approach taken by American Airlines, but differed markedly from that taken in the filings of other carriers, Id. 
following prescriptions: ${ }^{104}$ (1) the basis of the fare structure would be coach fares rather than first-class fares; (2) the fixed terminal-charge component of passenger fares would be raised to nine dollars (a substantial increase); (3) the mileage-charge component would be computed on the basis of five 500-mile blocks, with a decreasing per-mile charge for each successive block; ${ }^{165}$ (4) first-class fares would be set at 125 percent of day-coach fares, and night-coach fares seventy-five percent; (5) specified discounts from the coach fares otherwise applicable would be permitted in the case of certain promotional fares. On the basis of traffic movements in fiscal 1969, the Board estimated that the indicated changes would increase the industry's revenues by 6.35 percent. The Board's order further declared that the agency would consider fares derived by application of its formula as "a "just and reasonable' ceiling, and any fare in excess of this ceiling would be viewed prima facie as outside the realm of justness and reasonableness and would ordinarily be suspended and ordered investigated." 186

All of the carriers promptly filed new tariffs based upon the formula enunciated by the Board. Congressman Moss and his colleagues, as users of the airways and representatives of their constituencies, filed a petition for review in the court of appeals, challenging the Board's order of September 12 and its subsequent order denying their request for reconsideration. The issue, as stated by the court, was "whether the Board should have followed the procedures and standards established by Sections 1002 (d) [notice and hearing] and 1002(e) [factors to be considered in determining rates] of the [Federal Aviation] Act before proposing the rate schedule it set forth in its September 12 order." 187 The Board's position was that these provisions of the statute were inapplicable because the operative provision of the Board's order of that date merely suspended the tariffs filed by the carriers. ${ }^{108}$ Elaboration of a formula that would be regarded as an acceptable basis for computing the rates was, the Board argued, advisory-merely complying with section $1002(\mathrm{~g})$ of the Act, ${ }^{169}$ which directs the Board to state the

$164 I d$.

165 The taper of rates is a matter of considerable concern to carriers and one on which they hold sharply differing views-not surprisingly, in light of differences in route and traffic patterns.

168 C.A.B. Order of Investigation and Suspension, No. 69-9-68, Docket 21,322 (Sept. 12, 1969), quoted in 430 F.2d at 897.

167430 F.2d at 895. Section 1002(d), 49 U.S.C. $\$ 1482$ (d) (1970), provides that the Board "after notice and hearing" and acting "upon complaint, or upon its own initiative," may prescribe the rates or practices to be thereafter observed. Section $1002(\mathrm{e}), 49$ U.S.C. $\$ 1482$ (e) (1970), sets out 5 factors that the Board is to consider, among others, in exercising its ratemaking authority.

188 See 430 F.2d at $895,898$.

$169 \mathrm{Id}$. Section $1002(\mathrm{~g})$ is codified at 49 U.S.C. $\$ 1482(\mathrm{~g})(1970)$. 
reasons for its suspension orders. The carriers could have elected to stand fast on their original filings; they were under no legal compulsion to withdraw them and file substitutes conforming to the Board's suggestions.

The appeals court disagreed:

As a practical matter, the Board's order amounted to the prescription of rates because . . . the pressures on the carriers to file rates conforming exactly with the Board's formula were great, if not actually irresistible. All the carriers had indicated an urgent need for an immediate increase in revenues; the Board had made it clear . . . that only rates conforming to its detailed model would be accepted . . . . It explicitly stated that it would "consider fares produced by the formula as a 'just and reasonable' ceiling, and any fare in excess of this ceiling would be viewed prima facie as outside the realm of justness and reasonableness and would ordinarily be suspended and ordered investigated." 170

In sum, the Board forced upon the carriers "a complete and innovative scheme for setting all passenger rates for the continental United States." 171 This was done "after closed sessions with carrier representatives, without statutory public hearings and, according to petitioners, without reference to the rate-making standards of the statute." 172 If rates engineered by the Board in this fashion were to be treated as carrier-made rates because of the absence of a formal order in terms prescribing them, judicial review would be "practically nonexistent." ${ }^{173}$ Although objectors could file complaints directed to the rates that the Board allowed to take effect, "the Board's refusal to investigate would be reviewable only for abuse of discretion. And,

$170430 \mathrm{~F} .2 \mathrm{~d}$ at 897 (footnote omitted).

$171 \mathrm{Id}$. at 899 .

$172 I d$. at 900 . It may be noted that it was similarly contended in the Public Utilities Commission of California case, discussed above, text accompanying note 103 supra, that the agency (the FCC) was participating in ratemaking in closed sessions with A.T. \& T. representatives, without statutory hearings and without reference to statutory standards of ratemaking. The Moss opinion suggests, 430 F.2d at 899 n.33, that the California case is distinguishable because the Ninth Circuit's opinion did not indicate that the Commission had used the threat of its powers of suspension and investigation, or that it had advised the Bell System about the rate filings that would be acceptable. The distinctions are unpersuasive. If "continuous surveillance" is anything more than continuous subservience, it is only because A.T. \& T. is willing to pay a price for the avoidance of formal proceedings. Moreover, it is plain enough, "[a]s a practical matter," $i d$. at 895 , that the FCC becomes committed when it informally negotiates rate changes with the Bell System. Perhaps the District of Columbia court was not itself persuaded of the strength of these distinctions; it also observed that it had "no occasion to pass upon the wisdom of [the Ninth Circuit's] decision," as it involved "a somewhat different statute and a different industry . . . ." Id. at 899 n.33. 
of course, it would be very difficult indeed to apply this limited standard of review to a record made in large part behind closed doors." 174

On the facts of Moss, which showed an unusually heavy involvement by the agency in the fashioning of the rates, the court found persuasive basis for its holding that in fact, though not in form, the rates ultimately filed were Board-prescribed. Yet, it must be recognized that most orders of suspension will be influential in some measure-in some cases, to a very considerable extent-in shaping a carrier's future course of action. As earlier observed, the order of suspension commonly leads to withdrawal of the proposal, sometimes followed by the filing of a substitute. ${ }^{175}$ The agency, moreover, is called upon to state in writing its reasons for suspending. Obviously, the more informative the statement, the greater the likelihood (assuming that the carrier regards a formal case as an unprofitable venture) that it will shape the subsequent response. How far can the agency go in stating its reasons for suspending without running the risk that it will be found, "as a practical matter," to have prescribed rates in violation of statutory procedures? This Article has elsewhere argued ${ }^{176}$ that the ICC should provide the rate proponent greater guidance than that afforded by an empty paraphrase of statutory criteria. Does the Moss decision suggest that the agency does this at its risk; that obscurity is a virtue not to be despised?

It is apparent that there must be some accommodation between the provisions that confer the discretionary power to suspend rates pending investigation, a power designed to be interlocutory and not subject to judicial review, ${ }^{177}$ and the provisions that prescribe procedural safeguards and substantive standards for the agency's exercise of its reviewable authority to determine rates. If the power to suspend is employed in a fashion that coercively influences the carrier to acquiesce in a scheme of ratemaking designed by the agency-the conclusion reached by the District of Columbia Court of Appeals in Moss-the restraints upon the exercise of the federal ratemaking authority are avoided by merely altering the form through which the power is exercised. If, on the other hand, meaningful compliance with the statutory requirement that the agency state its reasons for exercising the power of suspension is enough to support an inference that it is engaged in ratemaking, little is left of the precept that the exercise of the suspensory power is a matter committed to the exclusive discretion of the agency.

$174 I d$. (footnote omitted).

175 See text following note 147 supra.

178 Text accompanying note 89 supra.

$177 \mathrm{See}$ the discussion of the history of the grant of the suspensory power to the ICC, text accompanying notes 15-37 sispra, 
The Moss court recognized the problem but concluded that the facts before it were so clear that it was unnecessary to decide "the exact extent of agency participation which will make an agency responsible for the rates being charged by carriers." 178

The decisive facts for the court were that the formula adopted by the Board in its suspension order was a complete, detailed, and innovative scheme, and that the pressures to accede to it were virtually irresistible. ${ }^{179}$ The further fact that the Board had met with the carriers in private sessions before reaching its solutions added weight to the court's conviction that the procedures ought not be countenanced. If this is a correct reading of Moss, the regulators face no serious dilemma. The agency can ordinarily state its reasons for believing that a proposal requires further investigation, without affirmatively seeking to formulate a detailed substitute. It is true, of course, that in some circumstances a meaningful statement of the deficiencies in the carrier's proposal will tell the carrier what will pass muster. Suppose, for example, that a carrier files for a general increase in its rates calculated to produce an added $\$ 1$ million in revenues. The material submitted in support of its filing shows that half of the proposed increase is designed to offset various increases in operating costs and that the remainder is based upon a claim that the agency should allow a fractional increase in a previously approved rate of return. Suppose, further, that the agency is satisfied that the asserted increases in costs have been correctly stated, and that a commensurate increase in revenues should be allowed, but that it is not prepared to accept without investigation the carrier's contention as to the appropriate rate of return. A statement to that effect would plainly inform the carrier that a substitute proposal designed to yield $\$ 500,000$ in added revenues would be

\section{F.2d at 898.}

179 The first of these findings is hardly open to challenge, and the second has substantial support. The Board itself acknowledged that the "compulsion" to file rates conforming to its formula was "undoubtedly great." Id. at 897 n.27. Given these findings, it is not surprising that the court found that there was a basis for judicial review despite the absence of a formal order directly enforcible by judicial proceedings. See Abbott Laboratories v. Gardner, 387 U.S. 136 (1967); United States v. Storer Broadcasting Co, 351 U.S. 192 (1956) ; Frozen Food Express v. United States, 351 U.S. 40 (1956); Columbia Broadcasting Sys. v. United States, 316 U.S. 407 (1942). See also the recent decisions of the District of Columbia Circuit in National Automatic Laundry \& Cleaning Council v. Shultz, 443 F.2d 689 (D.C. Cir. 1971) ; Independent Broker-Dealers' Trade Ass'n v. SEC, 442 F.2d 132 (D.C. Cir. 1971), cert. derried, 40 U.S.L.W. 3162 (U.S. Oct. 10, 1971) (No. 70-232); Medical Comm. for Human Rights v. SEC, 432 F.2d 659 (D.C. Cir. 1970), cert. granted, 401 U.S. 973 (1971) (No. 1162, 1970 Term; renumbered No. 70-61, 1971

Term). In the Broker-Dealers case, the court observed:

The vitality of the $C B S$ doctrine, in finding finality and reviewability of agency actions not issued as regulations or orders but having the consequence and contemplation of "expected conformity," is unmistakable.

442 F.2d at 141. 
accepted without suspension. The agency should do no less. The carrier should be told what is in issue and what is not. The Moss holding is not contrary. The example posed above would be proscribed by the court if the agency's order of suspension were to state, in express terms, that the carrier was entitled to $\$ 500,000$ in additional revenues, but that a tariff providing for such increase would be accepted without suspension and investigation only if it also provided for other changes, such as a specifically redesigned rate structure. Though in some situations the distinguishing line will be blurred, there is a workable distinction between a suspension order identifying the doubtful, unproved, or unacceptable aspects of a carrier's proposal, and one that seeks to use the agency's power to coerce the carrier into adopting changes lying outside the scope of its original proposal. ${ }^{180}$

\section{A Recommendation ${ }^{181}$}

As the Moss opinion observes, an agency may wish to respond quickly to a tariff proposal in order to meet "the immediate revenue needs of the carriers in times of rapidly rising costs." 182 Yet the agency may believe that the proposal should not be permitted to take effect without modification. The court suggests, in this connection, that it may be appropriate to initiate a formal proceeding and to grant interim relief when the circumstances are compelling. "Any approval of rates under such conditions would be subject to revision once more complete information is obtained." 183

The situation to which the court adverts is common. As rising costs appear to be a continuing phenomenon, and overbidding by the

$180 \mathrm{It}$ is likely, of course, that arguments will be made for the extension of Moss to situations in which the facts supporting judicial intervention will be less compelling than they were in that case. One notes in this connection that several recent decisions of the Court of Appeals for the District of Columbia Circuit go beyond familiar boundaries in finding finality and reviewability in circumstances in which no conventional order has been issued by the agency. See National Automatic Laundry \& Cleaning Council v. Shultz, 443 F.2d 689 (D.C. Cir. 1971); Independent BrokerDealers' Trade Ass'n v. SEC, 442 F.2d 132 (D.C. Cir. 1971), cert. denied, 40 U.S.L.W. 3162 (U.S. Oct. 12, 1971) (No. 70-232); Medical Comm. for Human Rights v. SEC, 432 F.2d 659 (D.C. Cir. 1970), cert. granted, 401 U.S. 973 (1971) (No. 1162 , 1970 Term; renumbered No. 70-61, 1971 Term). None of these cases, however, involved the power to suspend. The schemes of the statutes that deal with suspension of rates, the relevant legislative history, and a long line of judicial decisions strongly support the view that, at least in ordinary circumstances, an order of suspension is not judicially reviewable. See text accompanying notes 15-37 supra. See also cases collected in Long Is. R.R. v. United States, 193 F. Supp. 795, 797-99 (E.D.N.Y. 1961).

181 Although this proposal is presented in the context of a discussion of air carrier regulation, it applies as well to the other regulatory schemes considered in this paper.

$182430 \mathrm{~F} .2 \mathrm{~d}$ at 900 . 1970).

183 Id. at 901; cf. National Air Carrier Ass'n v. CAB, 436 F.2d 185 (D.C. Cir. 
rate proponent more expected than not, an agency is often convinced that some increase is justified and perhaps urgent, yet unconvinced that the carrier's proposal should be accepted in full. A system that requires the agency to suspend in full or not at all is needlessly inflexible and inflicts inequities that could be avoided. ${ }^{184}$ The device noted by the court in Moss, however, is not a complete answer, although it may provide a satisfactory solution in some instances. It contemplates interim orders in the course of formal proceedings based upon less-thancomplete findings. In some circumstances, a summary technique might serve this function far more effectively.

On occasion the federal agencies have sought to fashion a device by which they might allow a portion of a proposed increase to take effect in advance of a formal investigation of the carrier's filing. ${ }^{185}$ In a case noted earlier, ${ }^{186}$ the ICC suspended tariff schedules filed by the Alaskan Railroad. Subsequently, when the carrier petitioned for reconsideration, the Commission denied the petition, but without prejudice to the establishment, upon fifteen days' notice, of an interim increase not to exceed a specified amount. It further required that the publication of schedules providing for these interim increases carry a pledge to refund any amounts collected in excess of any increase subsequently approved or prescribed by the Commission at the termination of its investigation of the suspended tariff. As also noted above, the FCC employed a somewhat similar approach when A.T. \& T. filed for large increases in November $1970 .{ }^{187}$ It requested the company to postpone the effective date of the increases until the conclusion of an expedited hearing and granted special permission to file for interim increases that, the Commission indicated, would be suspended for a brief period and then permitted to become effective subject to account-

184 The federal regulatory statutes provide for suspending the operation of a tariff or schedule. They do not authorize suspension of a portion of an increase for which the carrier has filed, for example, for the suspension of one-half of a proposed $10 \%$ increase in a rate or fare. It may be noted that the agencies have assumed authority to suspend designated items when a single tariff or schedule contains a number of discrete items. Indeed, that is a commonplace in orders of suspension issued by the ICC.

185 In some instances, the information and data submitted contemporaneous with the filing of the proposed increase might show that the proponent was plainly entitled to a portion of the added revenues sought. In others, the agency might only obtain sufficient information to justify that conclusion at some stage of the formal hearing. As to the power of a regulatory agency to enter an interim order at an intermediate stage of the hearing process, see FPC $\mathrm{v}$. Tennessee Gas Transmission Co., 371 U.S. 145, 154-55 (1962); New England Division Case, 261 U.S. 184, 199-201 (1923); Panhandle E. Pipe Line Co. v. FPC, 236 F.2d 606, 608 (3d Cir. 1956).

186 Increased Rates and Charges, The Alaska Railroad, Interstate Commerce Comm'n, I. \& S. Docket No. 8604 (Sub No. 1), Order of Mar. 15, 1971.

187 American Tel. \& Tel. Co., 27 F.C.C.2d 149 (1971), discussed in text accompanying note 139 supra. 
ing and refund. ${ }^{188}$ The company complied, and the Commission suspended the interim increases for one week.

The agencies might proceed more expeditiously and with considerably less awkwardness if Congress were to grant them express authorization to permit temporary increases. Such legislation would also lay to rest any doubt as to whether action of the kind described above is consistent with legislative policy. It is anomalous to grant an agency unfettered discretion to suspend in full or to refrain entirely from suspending, yet make no specific provision for the common situation in which the agency can make a preliminary judgment that a proposal appears justifiable in part and questionable in part. A delay of six or seven months in making a change of rates effective may have heavy impact upon the carrier or utility caught in the squeeze of rising costs. Authority to grant temporary increases has been conferred upon state commissions in a number of jurisdictions and may be exercised in a manner providing not only relief for the carrier, but protection to the customer. ${ }^{189}$

New York law, for example, provides that the Public Service Commission may authorize "an immediate, reasonable, temporary increase" in rates charged by gas and electric utilities when it appears to the agency's satisfaction that the "public interest requires" an increase, or that it is "necessary for the purpose of providing adequate and efficient service, or for the preservation of the property." 190 It may impose such "terms, conditions or safeguards as it deems proper," including a prescription of the purposes for which the additional revenue shall be expended. ${ }^{191}$ Thus, temporary increases granted under New York law can be made subject to refund if the permanent rates prescribed by the Commission prove to be lower than those temporarily authorized. ${ }^{192}$

$188 \mathrm{Id}$. Under statutes that provide for refund of excess amounts collected during a period of suspension, an agency can, of course, grant immediate relief to the company by suspending the full increase for a very limited period-for example, one daywhile preserving for the ratepayers the ultimate prospect of a refund. This procedure, however, unfairly shifts to the customers, for what may well be a very substantial period of time, the burden of paying rates higher than those that the agency believes are justified. The refund remedy, moreover, is not only slow; it is also highly imperfect because, among other reasons, of the high mobility of the population. See FPC v. Tennessee Gas Transmission Co., 371 U.S. 145, 154-55 (1962).

189 See, e.g., N.Y. Pub. SERv. Law $\$ \S 66(12), 72,92(2), 97(1)$ (McKinney Supp. 1970-71); PA. Stat. ANN. tit. 66, $\$ 1150$ (a)-(e) (1959) (Pennsylvania Public Utility Code).

190 N.Y. PUB. SERv. LAW, $\$ 72$ (McKinney 1955). Identical provision is made in the regulation of telephone and telegraph companies. Id. \$97(1).

191 Id. $\$ 72$.

$192 \mathrm{Id}$. It is not uncommon under the New York practice for a company to file concurrently for a temporary increase and for a higher, permanent increase. Thus, this year the New York Telephone Company filed for a $29.1 \%$ rate increase calculated to yield added revenues of $\$ 391$ million. It also asked for a temporary increase of 
Such an approach is consistent with the structure of the federal regulatory statutes. Suppose, for example, that a carrier or utility that has been experiencing increasing costs and low earnings proposes a substantial, perhaps twenty percent, increase in its rates. Suppose further, that a conservative, preliminary estimate by the agency indicates that in all probability an increase of no less than ten percent will prove justified. Assuming that it possessed the necessary statutory authority, the agency could suspend the proposed twenty percent increase pending investigation; authorize the carrier to file without delay the ten percent increase; and impose as conditions of that authorization an obligation to make no further rate changes during the pendency of the investigation without further authorization, and an obligation to make refunds to the extent, if any, that temporary rates exceed the rates finally approved. ${ }^{193}$

This may be contrasted with the pattern likely to occur under present practices: the company files for a twenty percent increase, and the agency suspends; at the expiration of the suspension period, the full increases are made effective subject to refunds, since the investigation has not been completed; some months later, upon the conclusion of the proceeding, the rates are cut back, probably to a level somewhere closer to ten than to twenty percent.

Under the scheme first outlined, the company obtains added revenues without delay. If the agency's estimate of the situation is reason-

$20.7 \%$, calculated to yield $\$ 284$ million on an annual basis, pending determination of its application for the larger sum. The Public Service Commission has granted a temporary increase that will produce an estimated $\$ 190$ million per annum. See New York Times, Feb. 17, 1971, at 1, col. 6; $i d$., July 9, 1971, at 41, col. 1.

Consolidated Edison has also this year asked for an immediate increase that would yield $\$ 98$ million per annum in added revenues and a permanent increase that would yield $\$ 154$ million. New York Times, Apr. 1, 1971, at 1, col. 4. The company issued a statement that it could not "afford the usual lag of about one year between filing and approval ..." Id. 30, col. 4.

Rarely has the New York Commission granted a temporary increase and found, at the termination of its investigation, that it should fix the rates at a level lower than the temporary one. This did occur, however, in 1970, when the Commission first granted New York Telephone Co. an increase to yield $\$ 136.7$ million and ultimately decided that the increase should be $\$ 120.8$ million per year. The difference was ordered refunded. See New York Times, Feb. 25, 1970, at 1, col. 5; July 2, 1970, at 1, col. 1; and Sept. 4, 1970, at 23, col. 5 .

193 It is true that in certain situations the ordinary technique of ordering refunds may not be feasible. There is no billing arrangement or other form of regularized relationship between air carriers and the vast majority of their numerous passengercustomers; in such circumstances it would be extremely costly to impose a system of individual refunds. This, however, is not a serious objection to the grant of temporary increases in that industry. To begin with, the agency can exercise caution in setting the amount of the temporary increase, in order to minimize the likelihood that it would prove excessive. If it should nonetheless turn out to have been an excessive increase, the agency would have means of making an adjustment. It could direct that the permanent increase should take effect in two steps: at a level lower than would otherwise be warranted during the first stage, and at the level determined to be "just and reasonable" for the future in the second stage. In effect, this would provide a rough form of refund to the traveling public at large. 
ably accurate, but conservative, the company will get substantial relief but not so much of an increase that the burdensome business of making refunds to a large number of customers will ordinarily be necessary. Under the second approach, the company gets no relief during the period of suspension, the customers pay the company's "asking price" during the interval between the expiration of the suspension period and the termination of the case, and adjustment by a cumbersome process of making refunds concludes the drama. It seems plain that, employed in appropriate cases, the temporary increase can achieve a better balance of the equities and can operate to minimize the dislocations that are an inevitable part of the rate adjustment process.

\section{The Federal Power Commission}

The ratemaking authority of the FPC, which is conferred by Part II of the Federal Power Act and by the Natural Gas Act, directly affects three kinds of enterprises: electric utilities, natural gas producers, and natural gas pipelines. In each case, the rates subject to the agency's jurisdiction are those relating to sales in interstate commerce for resale. ${ }^{194}$ Filing requirements are similar to those fixed by the statutes discussed earlier, and the Commission exercises the customary powers of suspension and investigation, including authority to order refunds in situations in which increased rates have been put into effect following a period of suspension. ${ }^{195}$ The maximum period of suspension under both statutes is five months. ${ }^{196}$

Rate filings of electric utilities were suspended in only twelve instances in the decade 1961 to $1970 .^{197}$ Although there has been some increase during the past year, electric rate cases have been relatively few and of limited importance. ${ }^{198}$ At the other extreme, more than

194 Federal Power Act $\$ 201(\mathrm{~b}), 16$ U.S.C. $\$ 824 \mathrm{~b}$ (1970) ; Natural Gas Act $\S 1(\mathrm{~b}), 15$ U.S.C. $\$ 717 \mathrm{~b}(1970)$. As to the application of the Gas Act to producers, see Phillips Petroleum Co. v. Wisconsin, 347 U.S. 672 (1954).

195 Federal Power Act $\$ \$ 205,206,16$ U.S.C. $\$ \$ 824 d-e$ (1970) ; Natural Gas Act $\$ \$ 4,5,15$ U.S.C. $\$ \$ 717 \mathrm{c}-\mathrm{d}$ (1970). Under the Gas Act, the authority to file complaints with the Commission is conferred only upon a limited class: states, municipalities, state commissions, and, in some instances, gas distribution companies. Natural Gas Act $\$ \$ 5$ (a), 13 , 15 U.S.C. \$\$717d, $717 l$ (1970); cf. Federal Power Act $\$ 306,16$ U.S.C. $\$ 825$ e (1970). Neither act confers authority to grant reparations or damages for past unreasonable charges. See Montana-Dakota Util. Co. v. Northwestern Pub. Serv. Co., 341 U.S. 246 (1951).

198 Federal Power Act $\$ 205,16$ U.S.C. $\$ 824 d(\mathrm{e})$ (1970); Natural Gas Act $\S 4,15$ U.S.C. $\$ 717 \mathrm{c}(\mathrm{e})(1970)$.

197 Appendix F, based on statistics contained in undated letter from FPC Chairman John Nassikas to Mr. Roger C. Cramton, copy on file in Biddle Law Library, Univ. of Penna. Law School.

198 Since most electric utilities are integrated companies, i.e., are engaged in both the generation and transmission of electric energy, most of their sales are to ultimate consumers rather than sales for resale. With sales and exchanges between electric companies becoming somewhat more frequent, the importance of this area of the FPC's jurisdiction will surely increase. 
15,000 filings of natural gas producers were suspended during the same period. ${ }^{199}$ By and large, these suspensions did not involve individual exercises of discretion by the Commission. Rather, they reflected the Commission's program to establish area rate ceilings (as distinguished from individual company rates) in the producing fields. ${ }^{200}$ Pursuant to this program, the FPC has over an extended period automatically suspended all increases exceeding tentative ceilings (so called "guideline" prices) established pending completion of the various area proceedings. Cases resulting from these suspensions are not considered individually, but are consolidated with the relevant area proceeding, and the matter of refunds is determined in accordance with the decision in the area proceeding. ${ }^{201}$

There is little visible evidence that the FPC's use of its powers of suspension has deterred companies subject to its jurisdiction from initiating rate changes, and likewise little evidence that the Commission has sought to use those powers as a bargaining tool. During the decade of the 1960's, none of the filings of natural gas companies were withdrawn by the proponent. ${ }^{202}$ Only one electric rate was withdrawn after the Commission suspended it. ${ }^{203}$ In response to questions submitted to him, the present Chairman has stated:

The Commission does not follow the practice of advising filing parties in advance, either formally or informally, that it proposes to exercise its powers to suspend. Therefore, the Commission has neither undertaken to suggest to filing parties what kind of substitute filing would be acceptable without suspension, nor followed the practice of suspending a filing and then advising the filing party what kind of substitute filing would be accepted without suspension if the original filing were withdrawn.

There are occasions when a pipeline company will make an informal filing of a proposed rate increase with the Commission staff and its customers prior to filing its formal application for a rate increase with the Commission. The staff

199 Appendix $\mathrm{F}$.

200 For a discussion of the area rate program, see the opinion in the Permian Basin Area Rate Cases, 390 U.S. 747 (1968), in which the Supreme Court sustained the FPC's decision in the first completed area proceeding.

Recently, the Commission adopted the policy of suspending increases filed by producers for one day in situations in which it decides to enter upon a hearing. FPC Order No. 423, Feb. 18, 1971, 36 Fed. Reg. 3464-65 (1971) (to be codified at 18 C.F.R. $\$ 2.56(\mathrm{~g}))$. Although the order does not so state, this probably reflects the Commission's conviction that the prevailing ceiling prices are obsolete in light of the very substantial increases approved by the FPC in its recent Texas Gulf Coast Area Case, FPC Op. No. 595 (May 6, 1971), and therefore likely to be raised.

201 FPC Op. No. 595 (May 6, 1971). See also Southern Louisiana Area Rate Cases v. FPC, 428 F.2d 407 (5th Cir. 1970).

202 Appendix $\mathrm{F}$.

203 Id. 
is given an opportunity in these instances to review the data and work papers behind the Company's proposal and indicate to the company if the staff believes the proposed rates to be within the zone of reasonableness. Prior to filing its formal application, however, the company has not conferred with the Commission and has no assurance in advance of filing that the Commission will not exercise its power to suspend.204

The FCC, it will be recalled, has characteristically sought to avoid major cases by reaching advance agreement with the principal regulated company subject to its jurisdiction. The ICC had found that exercise of the suspension power deters the carriers from persisting in their requests in the great majority of cases. The CAB has frequently managed to short-circuit formal proceedings by signaling a proposed compromise through a "speaking" suspension order. The FPC has generally found, however, that orders of suspension almost inevitably lead to formal proceedings.

What is perhaps most significant in the FPC's experience from the standpoint of administrative procedure is that, unlike the other ratemaking agencies, it has found means of settling a substantial proportion of the formal cases that have gone to hearing. ${ }^{205}$ Although this takes the discussion beyond the primary area explored in this Article-the uses of the summary power to suspend-it is related in the sense that settlement has enabled the FPC to achieve in some degree what other agencies have accomplished in substantial measure at an earlier stage of the administrative process, the avoidance of the full-blown rate proceeding.

Cases involving the natural gas pipelines have long been the staple of the FPC's jurisdiction. The major pipelines all operate in interstate commerce and engage in sales for resale. Of 183 rate-increase filings received between 1961 and 1970 and subject to suspension, 117 (approximately sixty-four percent) were suspended. ${ }^{206}$ Almost all of them involved a request for general increases in rates. Those not suspended can generally be characterized as noncontroversial. ${ }^{207}$ In fifty instances

204 Letter from Chairman John N. Nassikas to Administrative Conference of the United States, Apr. 1, 1971, copy on file in Biddle Law Library, Univ. of Pa. Law School.

205 Although the FPC has made some use of settlement procedures in a few cases involving producers' rates, see Area Rate Proceeding, Southern Louisiana Area, FPC Op. No. 598 (July 16, 1971), the technique has been most commonly and successfully utilized in pipeline rate cases. The discussion that follows focuses on the latter category.

206 Appendix F.

207 Certain rate increases are routine and occasion no objection. Suppose, for example, that a pipeline's rates have been approved and that, shortly thereafter, its costs increase as a direct result of an increase in the rates charged by the producers supplying it. A "tracking" increase by the pipeline would presumably be allowed to take effect without suspension. Observations in this section of text are derived from sources cited note 208 infra. 
in which the rate was suspended, the Commission was able to effect a full disposition of the case by settlement procedures. ${ }^{208}$ In an additional seventeen cases, one or more contested issues were determined by settlement, and full proceedings were conducted to decide the remaining issues. ${ }^{200}$ Thus, disposition of some fifty-six percent of the FPC's pipeline rate cases was accomplished, in whole or in part, through the use of settlement procedures. There is no doubt that this has substantially aided the Commission in its efforts to keep abreast of its caseload. ${ }^{210}$

The settlements have taken place at various stages: some after the customary pre-hearing conference but before the commencement of hearings; others during the course of hearings; still others, after full hearing but before initial decision by the hearing examiner or final decision of the Commission. ${ }^{211}$ Agreements reached by the parties to a rate case are submitted to the Commission for its approval. Submission of briefs is omitted-although the parties may file commentsas is the initial decision of the hearing examiner, if not already made. ${ }^{212}$ If the agreement is approved, the Commission promulgates an order approving the settlement, perhaps with modifications or conditions, and making its terms effective. Although the order is ordinarily less elaborate than an opinion in a contested case, the Commission undertakes to explain the basis of its conclusion that the terms imposed are in the public interest and consistent with statutory standards. ${ }^{213}$

208 These may be most conveniently identified by the FPC docket numbers: RP $60-1$, RP $60-2$, RP $60-4$, RP $60-7$, RP $60-8$, RP $60-10$, RP $60-14$, RP 61-1, RP 61-2, RP 61-5, RP 61-6, RP 61-11, RP 61-13, RP 61-14, RP 61-15, RP 61-20, RP 61-21, RP 61-23, RP 62-1, RP 62-2, RP 62-4, RP 62-6, RP 63-2, RP 63-10, RP 64-5, RP 64-16, RP 65-2, RP 66-5, RP 66-6, RP 66-7, RP 66-8, RP 66-14, RP 66-19, RP 68-5, RP 68-6, RP 68-7, RP 68-9, RP 68-10, RP 68-20, RP 69-1, RP 69-3, RP 69-4, RP 70-1, RP 70-8, RP 70-9, RP 70-35, RP 70-37, RP 70-42.

209 The docket numbers are as follows: RP $60-3$, RP 60-5, RP 60-8, RP 60-9, RP 60-18, RP 61-3, RP 61-4, RP 63-1, RP 65-1, RP 67-21, RP 68-15, RP 68-16, RP 68-17, RP 69-13, RP 70-14, RP 70-29, RP 70-40.

210 Largely as a result of inflationary pressures, the caseload has been particularly heavy in the last several years. Of the 117 filings suspended during the period 1961-1970, 50 took place during 1969 and 1970. Appendix $F$. In those 2 fiscal years, 9 cases were settled in full (RP 69-1, RP 69-3, RP 69-4, RP 70-1, RP 70-8, RP 70-9, RP 70-35, RP 70-37, RP 70-42), and 4 were settled in part (RP 69-13, RP 70-14, RP 70-29, RP 70-40).

211 The Administrative Procedure Act provides that an agency shall give all interested parties opportunity to submit offers of settlement "when time, the nature of the proceeding, and the public interest permit." 5 U.S.C. $\$ 554$ (c) (1970). Congress considered the availability of such opportunity a matter of great importance. See Senate Comm. on the Judrciary, Administrative Procedure Act-Legislatrve History, S. Doc. No. 248, 79th Cong., 2d Sess. 24, 203, 261-62, 360-61 (1946). The courts also have laid stress upon use of the settlement technique. See, e.g., Michigan Consolidated Gas Co. v. FPC, 283 F.2d 204, 224 (D.C. Cir), cert. denied, 364 U.S. 913 (1960).

212 Even if the hearing has been completed prior to the time an agreement to settle is reached, the saving resulting from an abbreviation of the decisional process may be very substantial.

213 If all parties to a case agree to a settlement, it is a certainty that there will be no appeal. As it is pointed out below, however, the FPC has approved settlement proposals to which less than all of the parties subscribed. Case cited note 225 infra \& accompanying text. 
Whether a case proves susceptible of settlement obviously depends upon many variables, some of which may lie well below the surface. Even so, one can identify a number of factors that have made the climate favorable to resolution of pipeline rate cases.

(a) The FPC has long required the rate proponent to file specified information and data contemporaneous with its proposed tariff changes. ${ }^{214}$ In addition, the agency's practice is to call upon each party to prepare in written form and serve in advance the expert testimony to be offered as part of its direct case. ${ }^{215}$ As a result, the respective positions of the parties and the bases of their claims become fairly exposed at an early stage of the case.

(b) The agency's examiners have often, if not invariably, made effective use of the pre-hearing conference as a means of clarifying and defining issues, thus helping to lay a groundwork for discussions of settlement.

(c) The FPC staff has been a very active participant in rate proceedings, and its investigative capabilities have been regularly employed to check on factual claims made by the parties and to supplement their submissions. ${ }^{216}$ This contributes to the parties' sense that negotiation can take place on the basis of a reliable core of knowledge. The staff is also in a position to act, to greater or lesser degree, as a kind of intermediary or broker between the parties. The extent to which the parties may be swayed by the staff depends, to some extent, upon their estimate of the staff's influence with the Commission. On occasion, presumably when the parties were satisfied that the staff spoke for the agency, the staff has been conspicuous in its role of intermediary.

(d) Both the methodology that the FPC expects the parties to employ in "proving" a pipeline rate case and the standards that it applies in deciding such cases have been particularized by past practice

214 In the case of a proposed major increase by a natural gas company, the requirements are extremely detailed. See 18 C.F.R. $\$ 154.63$ (1971). The Commission's Rules state in pertinent part that "the material relied on in the filing . . . should be of such composition, scope, and format that it could serve as the company's complete case-in-chief in the event the rate is suspended ...."Id. $\$ 154.63$ (e) (1).

Until recently, similar requirements were not imposed upon electric utilities filing for increased rates. Comparable rules, however, have now been issued. FPC Order No. 429 Apr. $1,1971,36$ Fed. Reg. 6564 (1971) (to be codified at 18 C.F.R. $\S \S 35.13$ (b) (4) (v), 5 (i)).

215 The examiner is authorized to employ this procedure by 18 C.F.R. $\$ 1.26(\mathrm{c})$ (iii) (1971).

216 Participation is by the Office of the General Counsel, with professional and technical support from the Bureau of Natural Gas. The commitment of personnel to the conduct of the rate case has been more substantial at the FPC than at the FCC or the CAB. There is virtually no staff participation at the ICC, and the making of the record is left to the parties. 
and by decisions. This is not to suggest that the decisional process is inflexible or that policies are not subject to change. It is to say, however, that barring a shift in the composition of the Commission, the rules of the game and the standards of decision are sufficiently familiar that the result of litigating a case to the finish is apt to be fairly predictable. When estimates of the probable outcome do not vary widely, agreement is facilitated. ${ }^{217}$

(e) Generally, the principal adversaries in these cases are a pipeline company and the gas distribution companies that it supplies. ${ }^{218}$ While the pipeline and its customers have conflicting interests, ${ }^{219}$ they also have a considerable community of interest. Certainly they form a more homogeneous group than the contestants in most litigations. This is reflected in the attitude of their representatives, who are invariably experienced in the ways of the regulatory process and familiar with one another's positions.

Perusing these factors invites an attempt to find a general principle applicable to other agencies. While one must be cautious in seeking to apply one agency's experience to another, this much may be ventured: procedures that narrow the issues and provide for an early and full exchange of relevant data, when combined with a course of decisionmaking that makes the agency's standards visible and predictable, are the key to expedition.

Rate cases, particularly if they involve a general increase, may attract a substantial number of intervenors. The question arises as to what courses are open to an agency if there is wide, but less than unanimous, agreement on a proposal of settlement. Must it conduct a full evidentiary hearing for the benefit of one or two dissidents, or may it proceed to decision on the basis of written submissions and argu-

217 Inevitably, the terms of settlement are heavily influenced by decisions in contested cases involving similar issues. The Commission reported that in fiscal 1969 , cases determined by settlement negotiations resulted in allowance of "an average of about 50 percent of the rate increase amounts applied for." 49 FPC ANN. REP. 52 (1969). In fiscal 1970, the agency disposed of 10 pipeline cases, 8 of them by settlement. 50 FPC ANN. REP. 62 (1970). The increases approved in these 10 cases amounted to approximately $45 \%$ of the increases proposed. Id. Commenting on the cases terminated by settlement, the Anmual Report states that they were approved "after consideration as to whether they were sufficiently close in dollar amounts to what the Commission might have approved through the extended process of hearings, examiners' decisions, exceptions and possible court review." Id.

218 There may, of course, be additional parties, e.g., State Public Service Commissions, municipalities that own their own gas distribution systems, large industrial users of gas, or representatives of the coal industry (who are primarily interested in issues of rate design because of the competition between coal and gas in the industrial fuel market). When objections to a proposal of settlement are entered, they often come from one of these types of intervenors.

219 One conflicting interest is that of price, but that conflict may be blunted if the increase can be passed on without loss of business to competing forms of energy. 
ments, as the FPC has done in a number of instances? To pose an extreme case, suppose that counsel representing ninety-nine percent of a pipeline's customers agree to a settlement of the issues posed by the carrier's suspended rate but that one small customer, a company purchasing the remaining one percent, insists on an opportunity to crossexamine all of the company's witnesses whose written testimony has already been placed in the record.

Regulatory statutes call for a hearing-in the case of the gas and power acts, a "full hearing." 220 The Administrative Procedure Act provides a narrow escape hatch. Although trial-type procedures are prescribed when rules (defined in the Act to include ratemaking ${ }^{221}$ ) "are required by statute to be made on the record after opportunity for an agency hearing," 222 there is a caveat:

In rule making or determining claims for money or benefits or applications for initial licenses an agency may, when a party will not be prejudiced thereby, adopt procedures for the submission of all or part of the evidence in written form. ${ }^{223}$

Certainly, this exception is sufficient to authorize the agency to require the dissident to state the grounds of its objection to settlement and what it seeks to elicit by cross-examination. ${ }^{224}$ If the response shows that,

220 Natural Gas Act $\$ 4(c), 15$ U.S.C. $\$ 717 c(e)$ (1970); Federal Power Act $\S 205(\mathrm{e}), 16$ U.S.C. \$ $824 \mathrm{~d}(\mathrm{e})$ (1970). Although the term "hearing" assumes different meanings in different contexts, there can be little doubt, as Judge Henry Friendly has stated, that to the legislators who drew the Interstate Commerce Act (and this applies as well to the regulatory statutes modeled after it), the term "hearing"

meant what the Supreme Court had said in I.C.C. v. Louisville \& Nashville

Railroad, 227 U.S. 88, 93 (1913), "namely a proceeding in which all parties

must be apprised of the evidence submitted or to be considered, and must

be given opportunity to cross-examine witnesses, to inspect documents and to

offer evidence, in explanation or rebuttal" ... .

Long Is. R.R. v. United States, 318 F. Supp. 490, 497 (E.D.N.Y. 1970) (parallel citations omitted) (3-judge district court). See also Morgan v. United States, 304 U.S. 1 (1938) (requirements of a hearing under the ratemaking provisions of the Packers and Stockyards Act).

2215 U.S.C. $\$ 551(4)$ (1970).

222 Id. $\$ 553(\mathrm{e})$.

223 Id. $\S 556(\mathrm{~d})$.

224 Note that the so-called "modified procedure" rules of the ICC, 49 C.F.R. $\S \S 1100.45-.54$ (1971), commonly invoked by the agency, rest on the premise that an agency may provide for a determination on the basis of written submissions unless a request for an oral hearing is made and the basis of the request explained. Thus its Rule 53, id. $\$ 1100.53$, states:

(a) Request for cross examination or other hearing. If cross examination of any witness is desired the name of the witness and the subject matter of the desired cross examination shall, together with any other request for oral hearing, including the basis therefor, be stated at the end of defendant's statement or complainant's statement in reply as the case may be. Unless material facts are in dispute, oral hearing will not be held for the sole purpose of cross examination.

(b) Hearing issues limited. The order setting the proceeding for oral 
actually, no substantial factual controversy exists, a finding of "no prejudice" could be made. The same would be true if the agency were in a position to rule that the facts the objector proposed to establish would not in any event affect the decision.

The FPC, in a number of instances, has approved settlements that did not have the unanimous support of parties to the case, ${ }^{225}$ and on occasion this has precipitated an appeal to the courts. ${ }^{228}$ Either expressly or implicitly, the Commission has relied on the exception provided in the Administrative Procedure Act. The exception, however, is one of limited utility. The resourceful lawyer who has decided not to settle on the terms proposed-a determination that may spring from a belief that recalcitrance has nuisance value, from a conviction that delay itself is advantageous, or from a legitimate expectation of proving a valid point-will usually be able to base his demand for a full hearing on a plausible assertion that there are material issues of fact he wishes to explore. To override such a demand is to invite litigation.

Should the quoted exception in the Administrative Procedure Act be broadened, then, to facilitate the approval of a settlement proposal having substantial, but less than unanimous, support from those affected by a pending rate change? This might be accomplished by an addition along the following lines:

hearing, if hearing is deemed necessary, will specify the matters upon which the parties are not in agreement and respecting which oral evidence is to be introduced.

See Allied Van Lines Co. v. United States, 303 F. Supp. 742 (C.D. Cal. 1969); Gellhorn and Robinson, Summary Judgment in Administrative Adjudication, 84 HARv. L. REv. 612 (1971); Mohundro, Improvements in Procedure Before the Commission, 20 ICC PRAC. J., 75, 79-81 (1952); Woll, The Development of Shortened Procedure in American Administrative Lave, 45 CORNELL L.Q. 56, 62-66 (1959); cf. American Airlines, Inc. v. CAB, 359 F.2d 624, 632-33 (D.C. Cir.), cert. denied, 385 U.S. 843 (1966).

225 For a recent example, see Area Rates for the Appalachian and Illinois Basin Area, FPC Order No. 411, Oct. 2, 1970.

226 In Cities of Lexington, Etc., Ky. v. FPC, 295 F.2d 109, 119-22 (4th Cir. 1961), a settlement of a pipeline rate case was challenged by the single party (Lynchburg Gas Co.) that had refused to subscribe to the agreement. Iynchburg contended that the FPC, having suspended the pipeline's rates and announced that a hearing would be held, was required to go through with the hearing prescribed by $\$ 4(\mathrm{e})$ of the Natural Gas Act, 15 U.S.C. $\$ 717 \mathrm{c}(\mathrm{e})$ (1970), in the absence of unanimous consent. The Fourth Circuit rejected this contention on the ground that nothing in the Administrative Procedure Act "requires unanimous consent of all the participating parties to an agreement of settlement" and that to read such a requirement into the statute "would effectually destroy the settlement provision." 295 F.2d at 121.

More typical of the settlement orders apt to provoke litigation is the FPC's order in Manufacturers Light and Heat Company, Docket No. RP 69-16, Oct. 30, 1970, approving a settlement over the objection of Pennsylvania Gas and Water Company, one of Manufacturers' customers. The Commission's position was that, assuming the correctness of the underlying facts asserted by Pennsylvania Gas, the settlement was an appropriate one. Pennsylvania Gas, on the other hand, contended that an analysis of the agency's order showed that in fact it rejected petitioner's factual claims without a hearing, relying instead upon conflicting material submitted by other parties. The case is now pending on review. Pennsylvania Gas \& Water Company v. FPC, No. 71-1126 (D.C. Cir., filed Feb. 18, 1971). 
In a proceeding involving the prescription of rates for the future, if it appears that a substantial majority of the parties primarily affected agree to a proposal to settle one or more issues in the proceeding, the agency may, in its discretion, adopt procedures for the submission of all or part of the evidence pertaining to such issue or issues in written form. However, in determining whether there is substantial support for a proposal of settlement the agency shall consider the extent to which the parties to the proceeding are acting in a representative capacity. ${ }^{227}$

The objective of such a provision, of course, would be to expedite the multiparty rate cases that so often prove to be protracted and unwieldy. Preparation for cross-examination itself may extend over numerous hearing days. ${ }^{228}$ Moreover, it usually stimulates a further round of rebuttal testimony and cross-examination of rebuttal witnesses.

It should be added that, in the view of some observers, crossexamination has only limited utility in the typical rate case. Most of the "hard" evidence, they point out, is statistical and documentary, and its verification rarely depends upon the examination of witnesses. ${ }^{220}$

227 Since the focus of this study is on ratemaking, the proposal in the text is confined to that subject, though it might also be adapted to certain other types of proceedings. It should also be noted that the proposal could take the form of an amendment to 1 or more of the regulatory statutes conferring ratemaking powers, an approach that would permit experimentation on a selective basis. Two additional points may call for further comment. First, the term "primarily affected" is designed to enable an agency, in administering the proposed provision, to distinguish between the class of persons for whose benefit the statute was enacted (in the case of the Natural Gas Act, the consumers of natural gas) and those who, though they may have sufficient interest to justify intervention (such as sellers of a competitive form of energy), are not the intended beneficiaries of the statute. See National Coal Ass'n v. FPC, 191 F.2d 462 (D.C. Cir. 1951) (standing of coal producers in natural gas cases). Secondly, the final sentence of the proposal directs the agency to distinguish between an intervenor representing only his own interests (such as an industrial consumer of natural gas) and one representing a large class of affected persons (such as a state public utility commission or a municipality).

228 This is not to suggest that a party bent on prolonged cross-examination must be given his head:

The requirement of an evidentiary hearing is not a mandate of a prolix procedure protracted beyond endurance and beyond the requirements of the issues. Even in the most formal proceedings a capable hearing officer can evolve techniques that both expedite the proceeding and illuminate the issues.

Marine Space Enclosures, Inc. v. FMC, 420 F.2d 577, 590 (D.C. Cir. 1969).

228 Some years ago, the Attorney General's Committee on Administrative Procedure noted:

In the typical case tried in a court of law, there is frequently conflicting testimony by lay witnesses as to matters of ordinary fact; as a corollary, there is a distinct advantage in having the witnesses personally testify before the court in order that their veracity may be gaged from their conduct and demeanor. In a proceeding to fix rates or to determine the need for additional transportation facilities, much of the evidence is documentary in character, presented in the form of exhibits, and it is safe to say that at least 90 percent of the material which is presented by the direct testimony of witnesses could as well have been prepared in exhibit form. The information relevant to the fixing of rates is largely taken from the records of the 
Moreover, the opinions expressed in the testimony are largely those of trained experts, persons not likely to be trapped by counsel or caught in "[s] elf-contradiction under cross-examination." 230 They may be more effectively answered, it is suggested, by the opinions of other experts.

Yet, there are countervailing considerations. Cross-examination of an expert will sometimes prove revealing even if it does not show falsification or yield self-contradiction. Brice Clagett points out that " [a]n 'expert' making 'estimates' or 'forecasts' necessarily makes certain assumptions, relies on certain data, and engages in certain intellectual processes which he regards as rational." Why, he asks, "is it necessarily not useful to require him to testify about these matters, rather than allowing him to hide behind the anonymous expertise of an agency opinion writer ?" ${ }^{231}$ Judge Harold Leventhal, writing in a case that involved an agency's disposition of difficult legal-economic issues commented, "Even though there may be no disputed 'adjudicatory' facts, the application of the law to the underlying facts involves the kind of judgment that benefits from ventilation at a formal hearing." ${ }^{232}$ A point often neglected is that the examination of expert witnesses on the stand may provide clarification, understanding, and insight not easily derived from a welter of canned testimony or from counsel's advocacy. As one experienced examiner has put it, "An effective cross-examination can bring to life for the weary presiding examiner the nub of the controversy in a way that weeks and months of lonesome reading of the undiluted mass of written material could not possibly achieve." 233

These considerations carry weight. Accordingly, the proposal suggested above is not grounded on the proposition that cross-examination is of small use in rate proceedings and that therefore the dissident loses little or nothing if denied access to that tool. It rests rather on a pragmatic judgment composed of several ingredients: the adminis-

carrier and the [agency] and relates to such matters as traffic trends and operating costs. Conflicts as to the accuracy of data involving a determination of the veracity of particular witnesses are almost nonexistent.

Attorney Generaz's Comm. on Administrative Procedure, Monograpi No. 19, Civil Aeronautics Authority (1941), reprinted in Administrative Procedure iN Governasent Agencies, S. Doc. No. 10, 77th Cong., 1st Sess., pt. 6, at 38 (1941). 230 Prettyman, How to Try a Dispute Under Adjudication by an Administrative Agency, 45 VA. L. REv. 179, 190 (1959).

231 Clagett, Informal Action-Adjudication-Rule Making: Some Recent Developments in Federal Administrative Law, 1971 DUKE L.J. 51, 79 (emphasis in original). See also, Robinson, The Making of Administrative Policy: Another Look at Rulemaking and Adjudication and Administrative Procedure Reform, 118 U. PA. L. REV. 485,521 (1970).

232 Marine Space Enclosures, Inc. v. FMC, 420 F.2d 577, 589 (D.C. Cir. 1969). 233 Zwerdling, $A$ Plea for Clemency for Cross-Examination, 57 A.B.A.J. 45, 47 (1971). 
trative burdens imposed by rate cases can be significantly eased by the use of settlement procedures; the advantages to be derived from use of the settlement technique are considerably diminished if a dissident is in a position to force extended cross-examination by insisting upon the exploration of certain material facts and issues; cross-examination, though it has its values, need not be regarded as indispensable to the kind of quasi-legislative judgments characteristically made in rate cases; if a proposal of settlement is supported by a substantial majority of those primarily affected by a rate increase, the balance of considerations is altered, and there is an added basis for confidence that a solution within the proverbial "zone of reasonableness" is attainable without full-blown proceedings. In these circumstances, the proposed addition to the Administrative Procedure Act would permit, but not require, the agency to make its decision on the basis of written submissions.

\section{Postscript: A Note on Judicial Review}

A discernible trend has emerged, particularly marked in the Court of Appeals for the District of Columbia Circuit (where a heavy share of the cases are brought), in the direction of increased judicial review of federal agency determinations. More and more, the courts have come to look to the practical impact of agency action, or inaction, upon the complainants in circumstances in which there is no formal or final order in the traditional sense. ${ }^{234}$ Yet, even in those cases in which the courts have shifted somewhat the accustomed boundaries, they have purported to abide by certain limiting precepts: review will not be forthcoming if there is a "persuasive reason to believe" ${ }^{235}$ that it was clearly the purpose of Congress to preclude it, if the issues are inappropriate for judicial resolution, or if judicial intervention would be disruptive of the administrative process. ${ }^{236}$

234 See, e.g., National Automatic Laundry \& Cleaning Council v. Shultz, 443 F.2d 689 (D.C. Cir. 1971) (authoritative interpretive ruling of the Administrator of the Wage and Hour Div., Dep't of Labor, as to coverage of the Fair Labor Standards Act, held reviewable in advance of institution of enforcement proceedings); Independent Broker-Dealers' Trade Ass'n v. SEC, 442 F.2d 132 (D.C. Cir. 1971), cert. denied, 40 U.S.L.W. 3162 (U.S. Oct. 12, 1971) (No. 70-232), (SEC action, including writing letters to N.Y. Stock Exchange concerning the Exchange's minimum rate structure and related rebating practice, held reviewable, though letters were called "requests," because of pressures to conform that letters exerted); Medical Comm. for Human Rights v. SEC, 432 F.2d 659 (D.C. Cir. 1970), cert. granted, 401 U.S. 973 (1971) (No. 1162, 1970 Term; renumbered No. 70-61, 1971 Term) (no action letter issued by SEC in administration of its proxy rules held reviewable).

235 Abbott Laboratories v. Gardner, 387 U.S. 136, 140 (1967). See also Association of Data Processing Serv. Org., Inc. v. Camp, 397 U.S. 150 (1970); Barlow v. Collins, 397 U.S. 159, 167 (1970).

236 See cases cited notes 180, 234 stupra. See also Fahn v. Gottlieb, 430 F.2d 1243 (1st Cir. 1970), in which the court formulated the criteria for judicial reviewability of agency action as follows:

In the absence of a clear declaration of Congressional intent, three factors 
Judged by these considerations, the case against review of agency decisions suspending or refraining from suspending rates remains a strong one. This is not, of course, to deny what has been affirmatively stressed in the preceding discussion, that those decisions may indeed have immediate and significant consequences for the rate proponent and the rate payer. Rather, it is to assert the proposition, at times perhaps neglected, but hardly novel, that some questions of practical import remain that, all things considered, are better decided without the benefit of litigation in the courts.

As earlier elaborated, ${ }^{237}$ the history of the suspension provisions of the Interstate Commerce Act shows, clearly and convincingly, that Congress intended to settle the once disputed question whether the courts might exercise their equitable powers to enjoin a carrier from putting into effect a tariff schedule duly filed with the Commission, by entrusting solely to the agency the discretionary power to restrain such rate increases, subject only to the limitation that the suspension might not exceed the statutorily prescribed period. The Supreme Court has squarely adopted this view in Arrow Transportation Co. v. Southern Railway $\mathrm{Co}^{238}$ In that case, in which the equities in favor of a further restraint on railroad rate increases were particularly strong, ${ }^{239}$ the Court concluded that the judiciary had no power to grant relief. Although the holding went only to the point that the courts lacked power to impose their own injunction and did not rule on the question whether the courts have any authority to review an agency's exercise or nonexercise of its suspension power, the Court's reasoning is not so narrowly confined. Congress, it observed, was mindful of the "close nexus between the suspension power and the Commission's primary jurisdiction to determine the lawfulness and reasonableness of rates" and "meant to foreclose a judicial power to interfere with the timing of rate changes . . . "240 Nothing in the development of later regulatory statutes that conferred similar powers of suspension upon other ratemaking agencies detracts from this reading of the original intent.

seem to us determinative: first, the appropriateness of the issues raised for review by the courts; second, the need for judicial supervision to safeguard the interests of the plaintiffs; and third, the impact of review on the effectiveness of the agency in carrying out its assigned role.

Id. at 1249 .

237 Text accompanying notes $15-37$ supra.

238372 U.S. 658 (1963).

239 The controversy involved the expiration of a suspension order issued by the ICC. A complaining barge line had instituted judicial proceedings on the basis of allegations that it would be put out of business by the rail rates under investigation before the administrative proceeding could be concluded. Id.

$240 \mathrm{Id}$. at 668 (emphasis by the court). 
Pragmatic considerations point the same way. Consider, first, the case in which an agency has simply refrained from suspending a carrier's rate increase. Its inaction presumably reflects a determination that the proposed rate appears reasonable. The basis of its evaluation, however, is unknown. It may have rested upon any number of different grounds : an evaluation of data filed by the carrier in support of its proposal; information derived from the agency's files; inferences drawn from informal inquiries hastily initiated by the agency staff; specialized knowledge of conditions in the industry; the approach taken in other cases thought to be comparable; or a combination of any of these bases for judgment. Without the benefit of a record or findings, it is plain that no court would be equipped to pass upon the agency's exercise of discretion. On the other hand, requiring the agency to make the minimal kind of record and findings essential to meaningful review would be incompatible with the operation of the statutory scheme. The agencies face a veritable flood of filings, and the decision whether to suspend must be made within thirty days.

Much the same is true of the case in which the agency has affirmatively decided to exercise its power to suspend. If the sufficiency of the agency's reasons for acting were to be subjected to meaningful review, the court would need something more than their bare statement. Again, the volume of filings and the limitations of time and personnel preclude the adoption of procedures calculated to produce an adequate record. Even if there were some basis for conducting a satisfactory review of rate suspension orders, it is difficult to believe that it would often prove to be a productive enterprise. The agency's decision to suspend should be entitled to at least a presumption of correctness. The time spent in litigating the issue would run concurrently with the period of suspension. Thus, the issue of the validity of the agency's preliminary determination might become moot before it was decided by the reviewing court. Moreover, if the parties were to become enmeshed in a contest over the bases of the agency's decision to initiate its investigation, it would tend to disrupt the continuity of the agency's proceeding. ${ }^{241}$

241 Recent cases in which the federal courts did undertake to review orders of suspension are worth noting, even though they arose in statutory contexts other than ratemaking and turn on their own facts.

In Aquavella v. Richardson, 437 F.2d 397 (2d Cir. 1971), the Secretary of HEW had suspended Medicare payments to a nursing home that was almost entirely dependent on those payments for its revenues. The suspension was to continue until the Secretary determined, on the basis of a complete audit, whether the home had engaged in suspected irregularities. The plaintiffs sued for injunctive relief alleging that the Medicare Act did not authorize suspension of payments and that the Secretary was seeking to frustrate judicial review by suspending payments rather than terminating the agreement with the home (an action that would have been reviewable under the terms of the Medicare Act). The court ruled that the order of 
If, as this Article suggests, there are deficiencies in the exercise of summary power by the ratemaking authorities, the conclusion to be drawn is that the remedies had best be provided by Congress and the administrative agencies themselves.

suspension was "final agency action" reviewable under $\$ 10$ (c) of the Administrative Procedure Act, 5 U.S.C. $\$ 704$ (1970). The ruling rested, however, on the fact that the suspension had been in effect over 18 months without further formal action by the Secretary, and the court indicated that it would not have been likely to intervene at the stage of suspension "if there were regulations providing for a reasonably prompt administrative review of the preliminary action." 437 F.2d at 404.

In Environmental Defense Fund, Inc. v. Hardin, 428 F.2d 1093 (D.C. Cir. 1970), the complainants had petitioned the Secretary of Agriculture to exercise his emergency powers under the Federal Insecticide, Fungicide, and Rodenticide Act, 7 U.S.C. $\S \S 135-135 \mathrm{k}$ (1970), by suspending the use of DDT. The Secretary, who is authorized to suspend, pending the conduct of further expedited proceedings, upon a finding that such action is "necessary to prevent an imminent hazard to the public," Federal Insecticide, Fungicide, and Rodenticide Act $\$ 4,7$ U.S.C. $\$ 135 \mathrm{~b}$ (c) (1970), had taken no action on the suspension request. Noting that the complainants had submitted to the Secretary extensive evidence of the harmful effects of DDT and that, if they were right, "even a temporary refusal to suspend results in irreparable injury on a massive scale," 428 F.2d at 1099, the court concluded that "[t]he controversy over interim relief [was] ripe for judicial resolution ...." Id. Concluding, however, that it was impossible to provide meaningful review in the absence of a record, the court remanded to the Secretary, stating:

If he persists in denying suspension in the face of the impressive evidence presented... . , then the basis for that decision should appear clearly on the record. not in conclusory terms but in sufficient detail to permit prompt and effective review.

$I d$. at 1100 .

Cf. Nor-Am Agricultural Products, Inc. v. Hardin, 435 F.2d 1151 (7th Cir. 1970), petition for cert. dismissed, 402 U.S. 935 (1971). There, the Secretary had exercised his power to order an emergency suspension under the Federal Insecticide, Fungicide, and Rodenticide Act, and the complainants were persons engaged in the business of manufacturing and selling the banned product. The court, en banc, ruled that the interim order did not constitute "final agency action" and that judicial review was unavailable in advance of completion of the formal administrative proceeding. The Environmental Defense Fund case was distinguished on the ground that in that case "there were no further administrative proceedings available to the interested parties ..." Id. at 1159. 


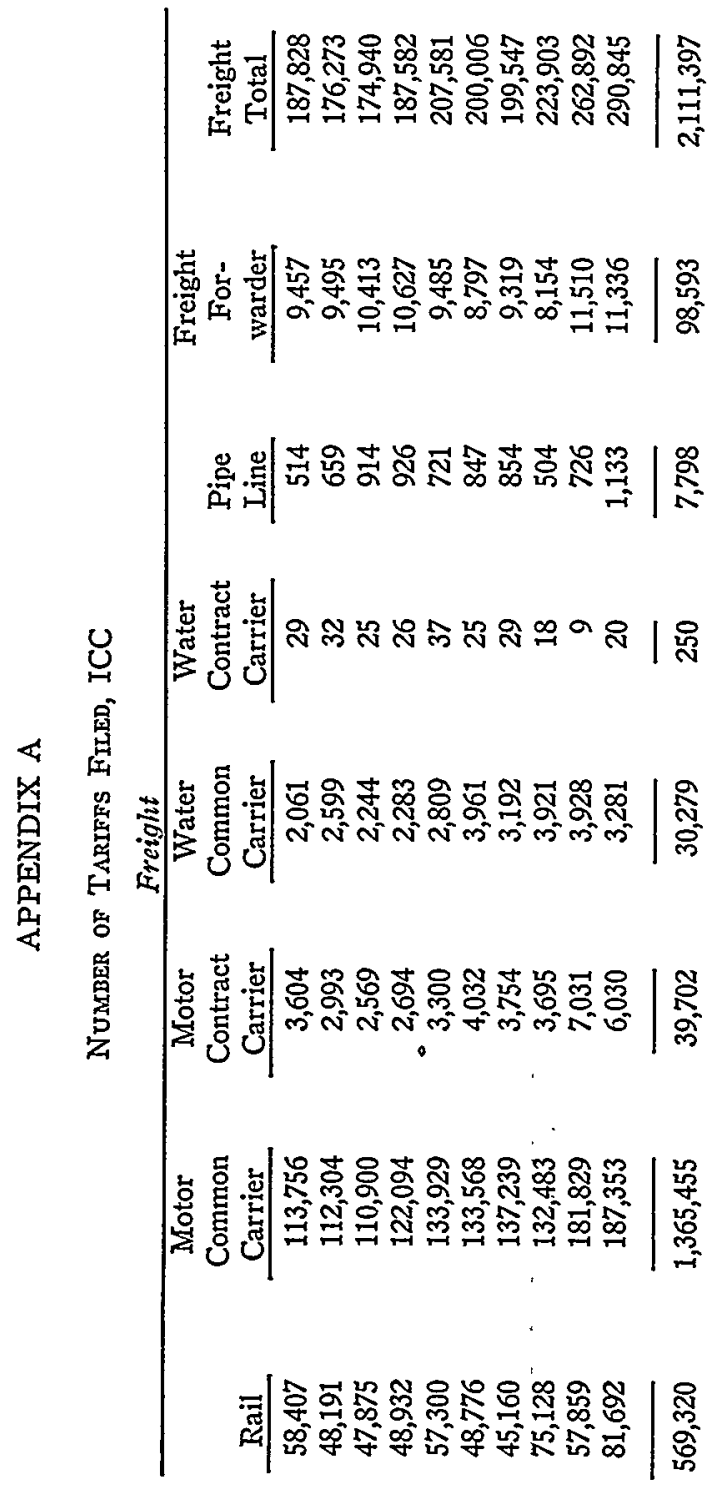

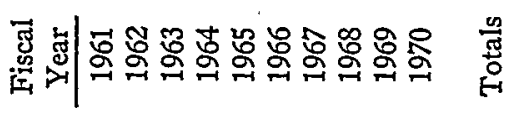




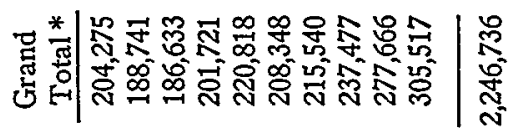

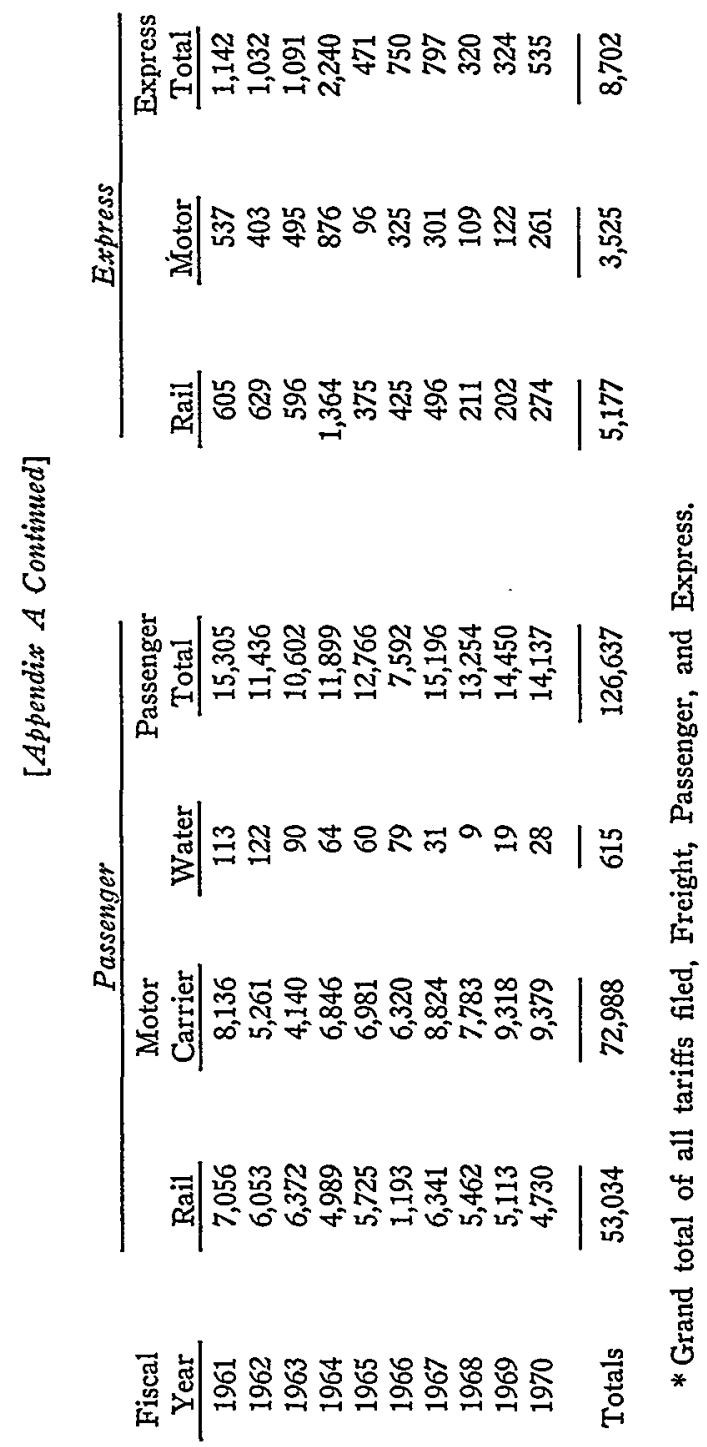




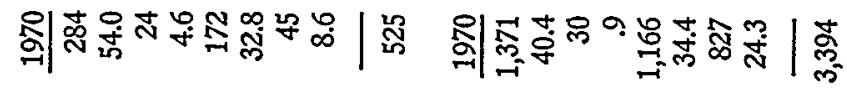

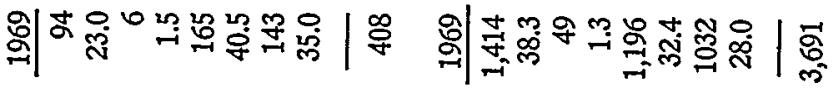

U.

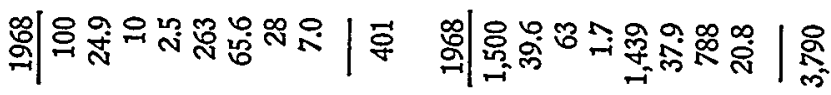

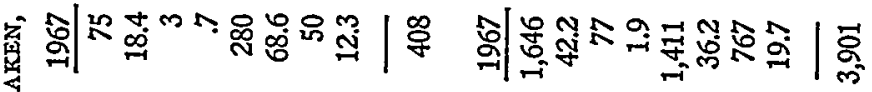

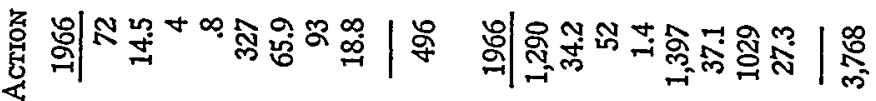

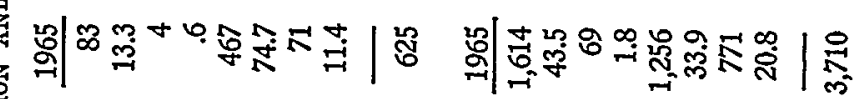

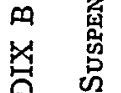

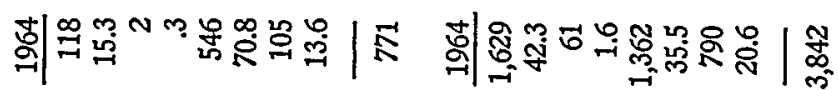

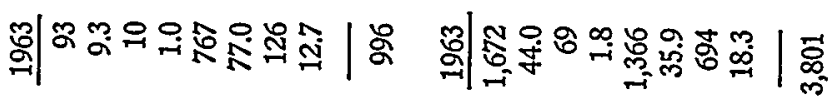

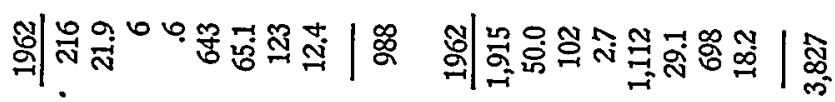

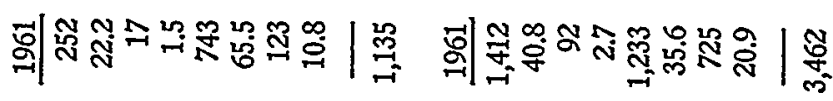

量

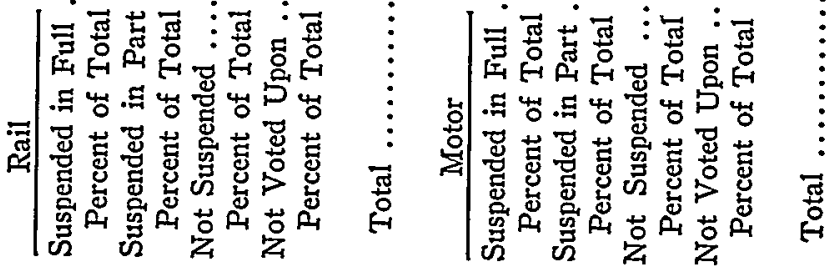




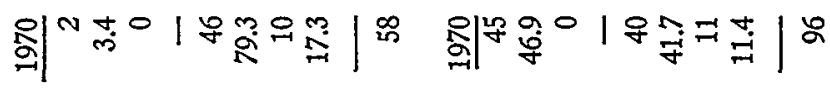

웜잉

言|ำ

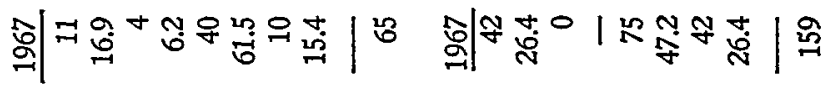

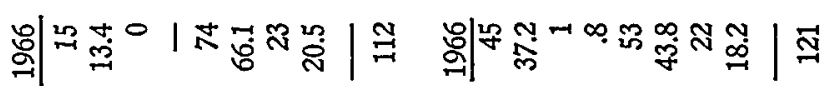

过|

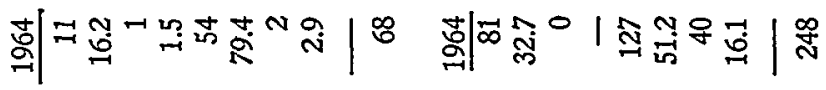

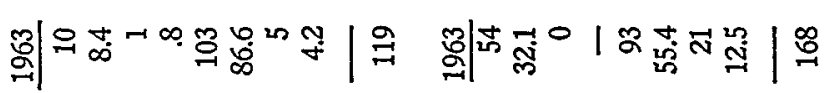

商|ํㅐㄱ

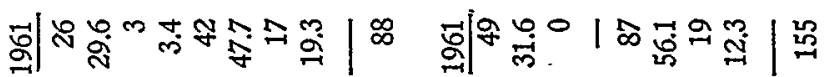

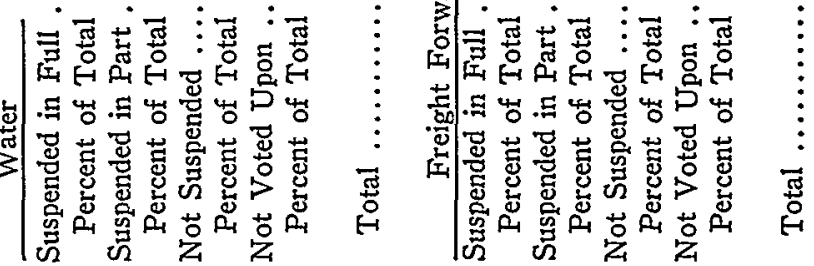




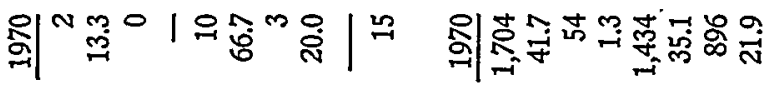

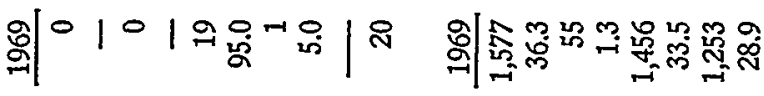

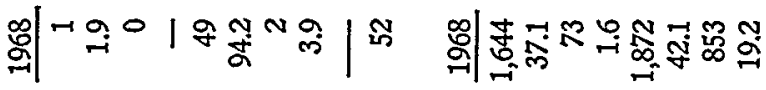

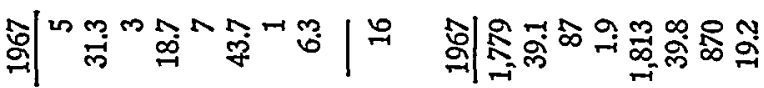

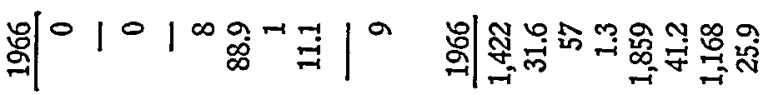

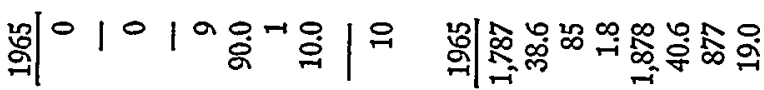

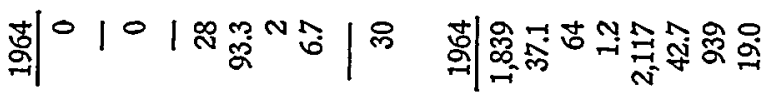

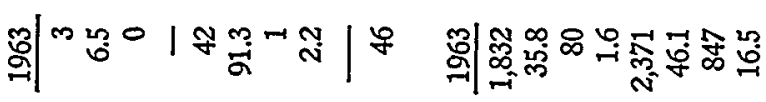

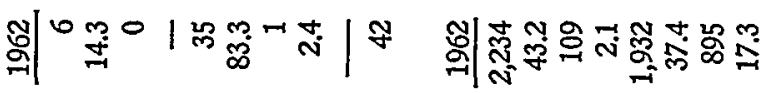

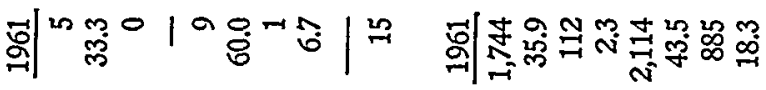

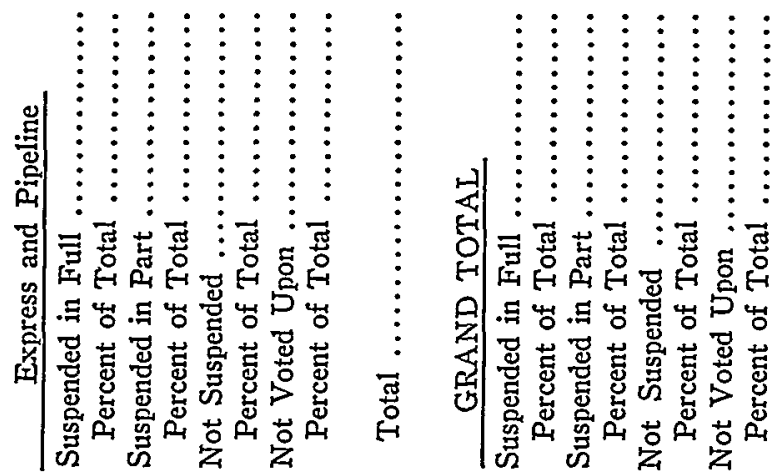




\section{APPENDIX C}

Tariff Publications and Suspension Proceedings, ICC

$\begin{array}{ccc}\begin{array}{c}\text { Fiscal } \\ \text { Year }\end{array} & & \begin{array}{c}\text { Total Number } \\ \text { Filed }\end{array} \\ 1961 & & 204,275 \\ 1962 & & 188,741 \\ 1963 & & 186,633 \\ 1964 & & 201,721 \\ 1965 & & 220,818 \\ 1966 & & 208,348 \\ 1967 & & 215,540 \\ 1968 & & 237,477 \\ 1969 & & 277,666 \\ 1970 & & 305,517 \\ \text { TOTAL } & & 2,246,736\end{array}$

Number Considered for

\begin{tabular}{c} 
Suspension, in Full or Part \\
\hline 7,590 \\
7,934 \\
8,378 \\
7,450 \\
9,341 \\
6,367 \\
6,540 \\
7,524 \\
6,974 \\
11,137 \\
\hline 79,235
\end{tabular}

\begin{tabular}{c} 
Percent \\
\hline 3.7 \\
4.2 \\
4.5 \\
3.7 \\
4.2 \\
3.1 \\
3.0 \\
3.2 \\
2.5 \\
3.6 \\
\hline 3.5
\end{tabular}

APPENDIX D

Protests FIned, ICC

$\begin{array}{ccc}\begin{array}{cc}\text { Fiscal } \\ \text { Year }\end{array} & & \begin{array}{c}\text { Shippers } \\ \text { and } \\ \text { Receivers }\end{array} \\ 1961 & & 1,402 \\ 1962 & & 916 \\ 1963 & & 1,408 \\ 1964 & & 1,213 \\ 1965 & & 1,405 \\ 1966 & & 1,129 \\ 1967 & & 2,129 \\ 1968 & & 2,753 \\ 1969 & & 2,528 \\ 1970 & & 3,454\end{array}$

\begin{tabular}{|c|c|}
\hline $\begin{array}{c}\text { Competing } \\
\text { Carriers }\end{array}$ & Total \\
\hline 3,987 & 5,422 \\
\hline 4,169 & 5,154 \\
\hline 3,853 & 5,333 \\
\hline 3,654 & 4,907 \\
\hline 3,367 & 4,845 \\
\hline 2,832 & 4,006 \\
\hline 2,375 & 4,572 \\
\hline 2,119 & 4,949 \\
\hline 1,929 & 4,507 \\
\hline 1,518 & 5,038 \\
\hline
\end{tabular}

\section{APPENDIX E}

Adjustments Consmered for Suspension, ICC

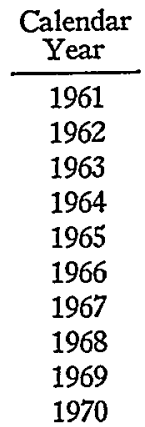

TOTALS
Total

Adjustments

Considered

for Suspension

5,262

5,035

5,055

4,874

4,602

4,380

4,501

4,580

4,076

4,329

$\overline{46,694}$
Total

Cancelled

Prior to

Effective Date

499

439

450

391

445

468

409

425

449

404

$\overline{4,379}$
Percent 

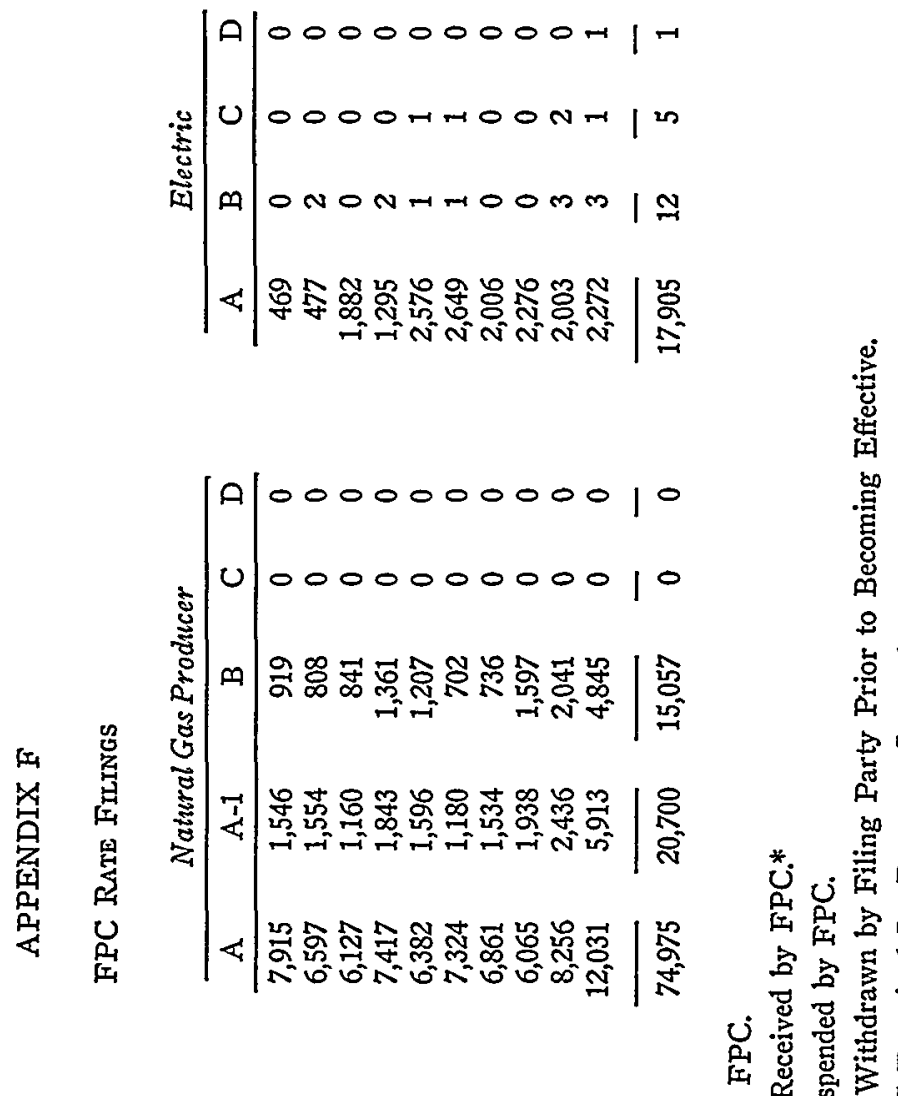

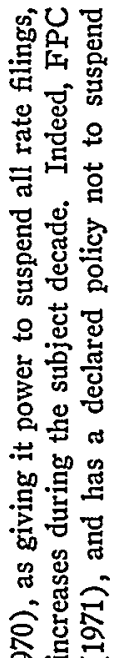

总

a.

4

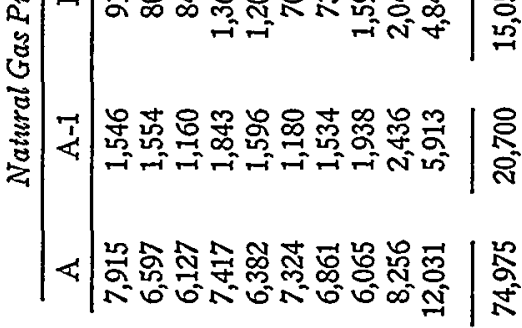

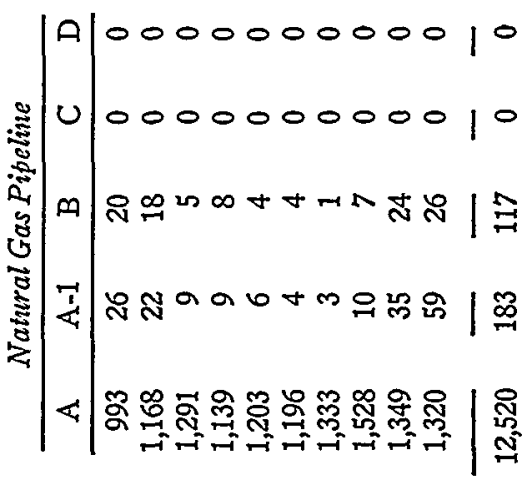

$\rightarrow$

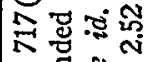

cos

Uุ

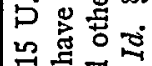

